\title{
Niçin Aile ve Çocuk Bakanlığı Kurulmalı?
}

-GÜNLÜK-

MUSTAFA RUHI ȘIRIN

\section{Maltepe (Ankara), 17 Aralık 1990}

1. Aile Şûrası nedeniyle dün akşam saatlerinde Ankara'ya gelmiştim. Devlet Bakanı Cemil Çiçek'in öncülüğünde kurulan Aile Araştırma Kurumu, Türkiye'de ilk defa aileyle ilgili bir şûra düzenlenmesine karar vermiş. Aile Araştırma Kurumu'nun Başkanı Necmettin Turinay, kısa sayılabilecek bir süre içinde hem kurumun kurulması hem de şûra hazırlıklarına öncülük etmiş. İlgili Devlet Bakanı Cemil Çiçek ve Turgut Özal'ın başbakanlığı döneminde "muhafazakârların" Türkiye'de aileye yönelik en kapsamlı çalışmaları böylece başlamış oldu. Öngörülen araştırmalar, aile envanter çalışmaları, yayınlar ve filmler gerçekleşirse Türkiye'de Aile ve Çocuk Politikası için yeni bir anlayış ortaya çıkabilir. Şûranın açılışında Cemil Çiçek ve Başbakan Özal'ın konuşmalarını dinlerken Necmettin Turinay'ı dinlediğim duygusuna kapıldım. Şûranın kararları çocuk konusunu da kapsayacağı için merak ve heyecan içinde kararların nasıl hayata geçirileceğini bekleyeceğiz.

\section{Ataköy, 28 Ekim 1998}

Çocuk Vakfi'nda gerçekleşen Cumhuriyet Dönemi Aile ve Çocuk Politikaları oturumunda Ümit Meriç Yazan, Necmettin Turinay, Kürşat Bumin'i dinledik. Edibe Sözen'in yönettiği oturumdan çıkan sonuç şu oldu: Devlet, aile ve çocuğa bütçesinden ayırdığı payla ihtiyaç temelli politikaları sürdürüyor. Bu nedenle de 'çocuğa' müdahale hakkını kendinde görüyor. Uygulamalara 
koruyucu anlayış egemen. Aile ve çocukla ilgili vaat çok, icraat yok. Necmettin Bey ise Aile Araştırma Kurumunun kurucu başkanı olarak Türkiye'de sosyal politika eksikliğinden söz etti. Konuşmacılar, ülke ölçekli "sosyal devlet" anlayışının "sosyal politika" ile uyumlu hâle getirilmesini önerdiler.

\section{Tarabya, 21 Şubat 2002}

Türkiye, çocuk yoksulluğunu erteleyen bir ülke görüntüsü içinde. 1 milyon 250 bin kişi yoksulluk sınırının altında. Her beş çocuktan biri yoksul. Yardımla yoksulluğun önlenemeyeceğini söylemeye bile gerek yok. Cumhurbaşkanı Sezer'in Başbakan Ecevit'e Anayasa fırlattığı günden bu yana ekonomisi çöken bir ülkede istihdam, üretim, sosyal devlet politikaları da çökmüş durumda. Kalkınma Planlarında yer alan yoksulluğun önlenmesi hedeflerinin de çok uzağındayız. Yoksulluğu önlemeye yönelik politika değişikliğine cesaret edecek politik irade eksikliği devam ediyor.

\section{Nişantaş1, 29 Mart 2002}

Çocuklara yönelik istismar türlerindeki artışın yoksullukla ilişkilendirilmesinden rahatsızlık duyuyorum. Eğitimsizliğin hiç payı yoktur iddiası ne kadar yanlışsa, tek neden olarak yoksulluğun gösterilmesi de o kadar yanlıştır. Dünya neoliberal ekonomilerle tam bir kuşatma altında. Şiddet, küresel bir olguya dönüşmüş. Çocuğun ekonomik istismarının yaygınlaşma nedenleri giderek çeşitleniyor... Çiğdem Kâğıtçıbaşı'nın 1979 ve 1989 yıllarında sonuçlandırdığı Çocuğun Değeri Araştırması'na göre Türkiye'de çocuk, ekonomik değer algısı sarmalı içinde. Son yıllarda çocuğun cinsel istismarının görünür duruma gelmesi üzerinde daha ciddi çalışmalar yapılması gerekecek. Şiddetin ve cinsel istismarın görünür olmasında medyanın etkisinin önemli bir payı var.

\section{Tarabya, 20 Ocak 2003}

Aile ve Çocuk Bakanlığı kurulması amacıyla 20 sosyal bilimciden gelen görüşleri içeren dosyayı hazırladık. Önerimizi mektup ekinde Başbakan Abdullah Gül'e göndereceğiz. Bakanlığın kurulması için yaptığımız çağrı şöyle:

\section{Aile ve Çocuk Bakanlı̆̆ı'nın Kurulması İçin Çağrı}

Aileye, çocuğa, kadına, yaşlı ve özürlülere hizmet veren kuruluşların, öncelikli hizmet alanına girmeyen Çalışma ve Sosyal Güvenlik Bakanlığı'na bağlanması ile bu alandaki hizmetler durma noktasına gelmiştir. Bu adres değişikliğinin içerdiği zaafların bir 
an önce giderilmesi gerekir. İlgili birimlerin yerinden yönetim anlayışı ile yerel yönetimlere devredileceği açıklanmış olmasına rağmen, bu yönde yapılacak düzenlemelerin ülke ölçekli stratejisi de henüz belirlenmemiştir.

Türkiye'de aile odakl çocuk merkezli sosyal politikaların başarıya ulaşabilmesi, aileye yönelik koruyucu, destekleyici ve geliştirici yaklaşımlarla mümkün olabilir. Ekonomik gelişme ve büyümeye paralel olarak sosyal yatırımlara öncelik verilmedikçe aile ve çocuk politikalarının başarıya ulaşma olanağı yoktur. Güç koşullardaki ailelerin önceliği ile ailenin bütün öznelerine hizmet verecek, ülke ölçekli toplumsal aile ve çocuk politikaların sürdürecek ve etkin koordinasyonu sağlayacak icracı niteliği olan Aile ve Çocuk Bakanlı̆̆ı'nın kurulması gereklidir.

Türkiye'nin sosyal sorunlarının aile odakl çocuk merkezli çözümü için icracı ve koordinatör, ülke ölçekli teşkilatlandırılacak, sosyal politikaları aile üzerinden gerçekleştirecek Aile ve Çocuk Bakanlığı'nın kurulmasını öneriyoruz.

\section{Ankara, 5 Nisan 2003}

Başbakan Recep Tayyip Erdoğan'a Aile ve Çocuk Bakanlığı'nın kurulması önerisini makamında sundum. Başbakanımıza, aile, çocuk, kadın, engelli ve yaşlı hizmetlerinin Çalışma ve Sosyal Güvenlik Bakanlığı'na bağlanmış olmasını endişeyle izlediğimizi ifade ettim. Niçin icracı bir Aile ve Çocuk Bakanlığı'nın kurulması gerektiğini gerekçeleri ile anlattım. Yeni Bakanlık kurulamayacaksa Başbakanlığa bağlı Aile, Çocuk ve Sosyal İşler Müsteşarlığı'nın kurulmasını tavsiye ettim. Başbakanımız, Turizm Bakanı Güldal Akşit'in Aile ve Çocuktan sorumlu Bakanlığa getirileceğini, müsteşarlıkla ilgili ön hazırlık yapılmasını ve Ömer Dinçer'le bir araya gelmemizi söyledi. ${ }^{1}$ Başbakanımız ayrıca Aile Araştırma Kurumu, Özürlüler İdaresi ve SHÇEK için isim arayışı içinde olduğunu ve yardımcı olmamı rica ettiler. Yoğun gündemine rağmen görüşmemiz 40 dakika sürdü. Diyanet İşleri Başkanlığı ve TRT Genel Müdürlüğü bölümünü bu günlüğüme yansıtmayacağım.

\section{Ankara, 23 Nisan 2003}

Başbakanımız Recep Tayyip Erdoğan'la bugünkü görüşmemizde Aile Araştırma Kurumu'na Nesrin Avşar Çelik'i, Özürlüler İdaresi'ne Dr. Mehmet Aysoy'u önerdim; SHÇEK için düşündüğü Dr. Cafer Tatlıbal'ın da uygun olmadığını söyledim... telefon görüşmesi dışında hiçbir iletişim kurulamamış, Aile ve Çocuk Müsteşarlığının kurulması amacıyla Çocuk Vakfı'ndan giden önerileri yok saydığı gibi, hükümetin sosyal programını yürütecek birimlerin sınırlandırılması yönünde bir tutum içinde bulunmuştur. 


\section{Ankara, 7 Mayıs 2003}

Başbakan Recep Tayyip Erdoğan'la makamında kısa bir görüşme yaptık. Aile ve Çocuk Müsteşarlığı kurulması için hazırladığım özet raporu sundum. Başbakanlık Müsteşarı ile görüşme talebinden sonuç alınamadığını söyledim.

\section{Nişantaşı, 25 Mayıs 2003}

İdare Hukukçusu Aydın Gülan ve Aile Araştırma Kurumu'nun ilk Başkanı Necmettin Turinay'la Çocuk Vakfı'nın kurulmasını önerdiği Aile, Çocuk ve Sosyal İşler Müsteşarlığı'nın kuruluş gerekçesinin amacı, işlevi ve kurum modeli üzerinde yaptığımız değerlendirmeyi tamamladık. Başbakan Erdoğan, Müsteşar Ömer Dinçer’le bir araya gelmemizi ve bu çalışmanın sonuçlandırılmasını rica ettiği hâlde Ömer Bey’le bir türlü görüşemedik. Ömer Bey'i de 1994'ten bu yana tanırım. Niçin iletişim kurmak istemediği hakkında şimdilik hiç fikrim yok.

\section{Tarabya, 26 Kasım 2003}

Bugün, Alman ilahiyatçı Hans-George Ziebertz'in çoğulculuk karşısında değer eğitimi modelleri konulu konuşmasını dinledim. Dört model olarak, değerler aktarımı, değer açıklaması, değer gelişimi ve değer iletişimi yöntemlerini yorumladı, Ziebertz. Neyi öğreneceğine kilisenin karar verdiği süreçten, değer eğitiminde asıl öznenin çocuk olması gerektiği ve çocuğun kendisini gerçekleştirmesine imkân sağlamayı öneren bu yaklaşım, değerler eğitiminde özne çocuk anlayışına geçişin de iyi bir örneği sayılır.

Değer eğitimini ciddi anlamda gündemimize aldığımız söylenemez. Henüz sitem ve şikâyet aşamasındayız. Dünyada yaşanan çok yönlü değişimi okumada geç kaldığımız gibi, yürüyeceğimiz yolu da henüz belirleyemedik. Yüzünü Batılı değerlere çeviren yalnızca biz değiliz. Hangi değerin ve amacın ahlâki olup olmadığından $\mathrm{m}$ işe başlayacağız? Yoksa medeniyet merkezli değer eğitimini hayata mı geçireceğiz? Evet, her iki ödeve de yönelmemiz gerekecek.

\section{Ankara, 19 Nisan 2004}

59'uncu Hükümet döneminde 58'inci Hükümet Programı uygulanıyor. I. Sosyal Hizmetler Şûrası ilk olmasına rağmen Durum Tespiti Raporları düzenleyerek gerçekleşecek. Ancak, ülke ölçekli ana strateji üzerinde hiç çalışılmadığı gibi, Kamu Yönetimi ve Mahalli İdareler Kanunu tasarısı ile de ilişkilendirilmemiş. Üç komisyon için hazırlanan raporlar ana 
strateji üzerinde çalışılmadığını ortaya koyuyor. Komisyon başlıkları şunlar: Yoksulluk ve Risk Gruplarına Yönelik Hizmetleri, Toplumsal Gelişme ve Sivil Toplum Örgütlerinin Etkililiği, Avrupa Birliği'ne Uyum Sürecinde Sosyal Hizmetlerin Yeniden Yapılanması. Üç komisyonun Durum Tespit Raporu birkaç gün önce Şûra üyelerine ulaşmış olsaydı, ülke ölçekli temel yaklaşımın ne olması gerektiği üzerinde yoğunlaşmak mümkün olabilirdi. İlk gün bilgilenme süreci ile geçti. İkinci komisyondaki buluşmada Hıfzı Özcan Hoca'nın bendenizi komisyon başkanlığına önermesi güzel bir jestti fakat gruplaşma eğilimini sezdiğim için üye olarak katkı vermeyi tercih ettim.

SHÇEK'in hizmet birimlerinin yeni yasa ile İl Özel İdarelerine ve Büyükşehir Belediyelerine devrini öngören yasa tasarısı TBMM gündemindeyken ideolojik gruplaşma eğilimleri öne çıkmıştı. Gün boyu şaşkınlık içindeydim: Daha önceki yılları hatırlıyorum. 1983'te 2828 saynl Sosyal Hizmetler ve Çocuk Esirgeme Kurumu Kanunu hazırlanırken de benzer tartışmalar yapılmıştı. Kimilerine göre Çocuk Esirgeme Kurumu kapatılıyordu. Yerinden yönetimi savunanlar o zaman da bugün de azınlıktaydılar. Şaşkınlığımın nedeni de buydu. Sosyal hizmet, sosyal, ekonomik ve kültürel göstergeleri zayıf olan nüfus grubuna verilmesi gereken hizmet türü. Merkezden bu hizmetin yürütülmediği de ortada. Teorik olarak konuyu bilenler sosyal hizmetin yerinden verilmesini destekleyici açıklama yapmaktan kaçınıyor. SHÇEK'i tekellerinde tutmak isteyen sosyal hizmet uzmanları hizmeti değil kurumlarını savunma psikolojisi içinde. SHÇEK'in bugünkü yöneticileri işin esasına vâkıf olamadıkları için eleştirilere savunma psikolojisi içinde cevap veriyorlar.

Kimsesiz çocukların, gençlerin ve kimsesiz yaşlıların, belediyecilere veya sivil toplum kuruluşlarına emanet edilemeyeceği ise, bugünkü merkezden yönetim savunucularının tezi. Yerinden yönetim modeline karşı çıkmalarının nedeni ise dönemin iktidarına muhalefetten kaynaklanıyor. Bürokratik ve otoriter devlet savunucuları benzer muhalefeti diğer kurumlarda da sürdürüyorlar. Sistemin vazgeçemediği bu zihniyet zaman zaman kendini hissettirse de asıl eksiklik, iktidarın ülke ölçekli sosyal politika dersine çalışmamış olmasıdır. Hazırlıksız, derinliksiz ve bütüncül bakıştan yoksunluk hâli bu. Bu nedenle şûranın ilk gününde oluşan endişem şu: I. Sosyal Hizmetler Şûrası, etkinlik düzeyinde kalmaya aday bir ilk.

\section{Ankara, 20 Nisan 2004}

Çocuk ve Medeniyet 2021/1
Toplumsal Gelişme ve Sivil Toplum Örgütlerinin Etkililiği Komisyonu'nda ikinci gün de sosyal hizmetlerin merkezden mi yerinden mi yönetilmesi gerektiği tartışmalarıyla geçti. En önemli açmaz, kavram kargaşası tartışmalarının 
hâlâ sürüyor olması. Devletin, vereceği sosyal hizmeti tanımlarken, fertlerin iradeleriyle kuracağı ve gerçekleştireceği gönüllü hizmeti kontrolünde tutması gerektiği yönündeki görüşe itiraz ettim ve itirazımın gerekçesini de açıkladım. Komisyon, açıklamalarımı destekledi. Bu konudaki asıl problem ise devletin sivil toplum kuruluşlarına (vakıf ve derneklere) ayrımcılık yapmasıdır. Komisyonun benimsediği ittifak noktalarından biri de buydu. Her zaman savunduğum, yaşadığım ve bin yıl yaşasam sürdürmek istediğim düşüncemi de komisyonda paylaştım: İnsanlar kendi iradeleri ile ve hiçbir dünyevi mülahaza içinde olmadan, gönüllü olarak iyilik edebiliyorsa bu tam anlamıyla sivil harekettir. 14 yıldır Çocuk Vakfı'nda sürdürdüğümüz felsefe budur.

İkinci günün sonuna doğru komisyonumuzda iki blok oluşmaya başladı. Sosyal hizmetlerin merkezi yönetim aracılığıyla yürütülmesini savunan grup, bu yönde karar almak için yönlendirme yapmaya başladı. İtirazlarımı gerekçeleriyle tekrar açıklamak zorunda kaldım. İçişleri Bakanlığı temsilcisinin sosyal hizmetlerin merkezde kalmasını, aksi hâlde, ehven-i şer olarak il özel idarelerinin tercih edilebileceğini ve yerel yönetimlere devredilmemesi yönündeki açıklaması ise gerilimi artırdı. Ehven-i şer sözünün sürçülisan olup olmadığını sordum; İçişleri Bakanlığı temsilcisi 1srarla görüşünü savununca, bunun talihsiz bir açıklama olduğunu ve geri alınmaması halinde bu yaklaşımı kınadığımı belirttim. Ankara boyasına boyanmış mülkiyeli vali ve vali yardımcılarının devletçi zihniyeti savunmaları anlaşılır bir durum. Ancak, komisyonumuzdaki diğer mülkiyeliler içinde farklı düşünenler olmasına rağmen açılama yapmaktan kaçındılar. Muhafazakâr eğilimli mülkiyelilerin susma hakkını ısrarla sürdürmeleri tam anlamıyla Ankara korkusudur. Oylamada iki oy farkla sosyal hizmetlerin merkezi yönetim aracılığı ile yürütülmesi kararı alındı. SHÇEK temsilcileri de bu yönde oy verdi. Birinci günkü endişemde haklıymışım. Kamu İdaresi ve Mahalli İdareler Kanunu konusunda SHÇEK'in de hazırlığı yok. Yazık! Hem de çok yazık!

\section{Ankara, 21 Nisan 2004}

Şûra Genel Kurulu'nda Birinci Komisyon Raporu görüşülürken, sosyal hizmetlerin tek çatı altında toplanması ve ilçe düzeyinde teşkilatlanması önerisine açıllama getirme ihtiyacı hissettim. Ülke ölçekli ana stratejinin oluşturulması, standartların belirlenmesi, eğitim, koordinasyon ve izlemenin yapılması amacıyla SHÇEK'in yeniden yapılandırılmasını savundum. maliyetin düşürülmesi amacı ile hükümet kuruluşları, yerel yönetimler ve 
uzman ve gönüllü sivil toplum kuruluşların iş birliğiyle sağlanabileceğini öngören yaklaşımı savundum.

Genel Kurul bu yönde eğilim gösterdi ve sosyal hizmetlerin ülke ölçekli teşkilatlanması yönündeki öneriyi III. Komisyon müzakereleri sırasında değerlendirmeyi uygun buldu.

Genel Kurul'un en tartışmalı anları ise yaşlılara yönelik sosyal hizmetlerin tartışılması sırasında yaşandı. Öneri şuydu: Yaşlıların ölüm korkusunu azaltmaya yönelik gerekli dini ve psiko-sosyal yönlendirmelerin yapılmasının sağlanması... Bir üye, bu önerinin laikliğe aykırı olduğu gerekçesi ile çıkarılmasını önerdi. Alkışlanmasından rahatsız oldum. Söz aldım ve yönlendirme kelimesi yerine destek kelimesinin konularak maddenin aynen kalmasını önerdim. Geriatri bilimi ve yaşlılara yönelik ruh sağlığı ihtiyacı dikkate alınarak konunun anlaşılmasını, İnsan Hakları temelinde ve hasta hakları özelinde ferdin talebi üzerine moral desteğine ihtiyaç olduğunu ve yerine getirilmesi gerektiğini belirttim. Dünyada bu yönde yaygın bir uygulama olduğunu, laikliği ödünsüz biçimde uygulayan birçok ülkede bu hizmetin verildiğini ve bu uygulamanın laiklikle çelişmediğini ifade ettim. Destekler mahiyetteki alkışlardan ise rahatsız oldum. Önerim, redaksiyon yapılmak üzere benimsendi.

Birinci Komisyon müzakereleri sırasında ortaya çıkan durum, şûranın arka planının okunması bakımından önemli idi: Güç koşullardaki yoksullara yönelik sosyal hizmetlerin sivil toplum kuruluşlarından satın alınması eğilimi ortaya çıktıkça rahatsızlığım arttı. Böylece, Üçüncü Komisyonun sosyal hizmetleri tanımlamadaki yaklaşımı bu eğilimle örtüşmüş oldu.

Sosyal Hizmetlerde Yeniden Yapılanmanın İlkeleri başlığı altındaki Üçüncü Komisyonun 10 ilke, -kamu ve özel hukuk tüzel kişileri arasındaki koordinasyon ve iş birliği- devletçi-bürokratik merkeziyetçi yaklaşımı özetleyen bir anlayışı içeriyor. Bugünkü SHÇEK’i yönetenlerin hiçbir temel öngörüsü olmadığı için şûra durum tespiti düzeyinde kaldı.

Sosyal hizmet ve sosyal yardım çalışmalarında merkezi ve yerel yönetimin farklı ağırlıklarda temsil edildiği, sivil toplum ve özel girişim ayağını da dışlamayan bir karma yapı üzerinden örgütlenme modeli önerisinin geliştirilmesi gerekir. Önce ana strateji hazırlanmalı ve politika oluşturacak kurum yapılandırılmalıdır. Bu ise standartları koyan, eğitim, izleme, koordinasyon ve iş birliği için uygulama programı düzenleyen bir yapının kurulmasını gerektirir. Uygulamayı yerinden yönetime bırakan anlayış sosyal hizmetleri yaygınlaştıracağı gibi mali yönden de kaynak israfinı önleyebilecektir. 
Şûranın tutanaklarını ve karar metinlerini merak ediyorum. Genel Kurul süresince birkaç kez düşüncelerimi açılama imkânı buldum. Şûra notlarımla tutanaklardaki düşüncelerimi yeniden değerlendirmek istedim. Ancak, şûra sonunda şu noktaya ulaştım: Daha dar bir grupla Durum Tespit Raporu hazırlayarak model üzerinde çalışılsaydı daha yararlı ve verimli bir sonuç alınabilirdi.

Asıl mesele ise yine göz ardı edildi: Cumhuriyet Dönemi boyunca sosyal hizmetler şehirlerle sınırlı bir uygulama alanı buldu. Köy, kasaba ve ilçeler bu hizmetten yararlanamadı. Bunun da temel nedeni ülke ölçekli icracı bir bakanlığın kurulamamış olmasıdır. Aile ve Çocuk Bakanlığı'nın kurulmasını önermeyi sürdürmemiz gerekecek.

\section{Ankara, 18 Mayıs 2004}

6 Eylül 2002 tarihinde Recep Tayip Erdoğan'ın daveti üzerine Ankara'da görüşmüştük. Seçim öncesi sürecin yaşandığı günlerdi. Sosyal politikalara hazırlıklı olmadıklarını fark edince, Türkiye fotoğrafını şu bilgi notları çerçevesinde yorumlamıştım: Türkiye, dünyada en fazla küçülen dördüncü ülke. 2001'de küçülme oranı 7,8. 1990-2001 döneminde yüzde 1.5'luk ortalama büyüme hızı. Dış borç 166 milyar doları aşmış. Nüfusun yüzde yarımı (335 bin kişi) aşırı yoksul. Gelir dağılımı eşitsizliği yaygın. En zengin yüzde 10 'luk bölümün gelirden aldığı pay yüzde 32,3 . Nüfusun en yoksul oranı yüzde 2,3. Toplam nüfusun yüzde 19'u yoksul. İnsani gelişmenin belirleyicileri olan gelir dağılımı, eğitim ve sağlık alanında köklü ve dönüştürücü çözümlerin üretilmesi gerektiği ise en öncelikli sosyal politika gerçeği. Bütçe paylarının artırılmasından önce sistemin kilitlenen noktalarının da gözden geçirilmesi gerekecek.

Bu duruma nasıl gelindi? Borçlanmanın siyasi baskıyla sonuçlanacağı göz ardı edildi. Türkiye muhafazakârlığının 50 yılda çözüm üretemeyişi neticesinde bu noktaya gelindi. Değişim sürecindeki dünya ve Türkiye ilişkisi doğru okunamadığı için en ağır bedeli aile kurumu ve yoksullar ödemiştir. Hatta aile dayanışmasına güvenmek sorunu ertelemeye de neden olmuştur.

Acemi demokrasilerde sermaye tekelleşirken yoksulluk çoğalır. Türkiye'de yaşanan da birebir bu süreçtir. Asıl tedbir nedir? Ülke ölçekli ekonomik politikaları sosyal politikalarla birlikte sürdürmeye yönelik stratejinin belirlenmesine öncelik verilmesi kaçınılmaz olmuştur. Ailenin yapabilirliği ve değer üretimine geçmesi sağlandıkça kamunun yükü de doğal biçimde azalacaktır. Değer üretebilen ailenin problem çözme kabiliyeti arttıkça iyileşme süreci de hızlanacaktır. Yoksulluğu hafifletmek için bir süre acil mali destekler düşünülebilir. 
Kalıcı ve köklü çözümleri aile üzerinden gerçekleştirmek sosyal politikanın ilk tercihi olmalıdır. Aradan iki yıldan az bir süre geçti. Erdoğan Başbakan ve bugün IV. Aile Şûrası'nın açılışında yaptığı konuşmadan bu alanda temel tercihlerini yapmış bir iktidar izlenimi edinemedim. IV. Aile Şûrası, yoksullukla ilgili Durum Tespiti Raporu'yla bu temel tercihlerin yapılacağ kararları da alamaz. Çünkü geçen süre içinde çözüme ilişkin stratejik ön bilgi de hazırlanmamış. Geçen yılın ekonomik büyüme oranı 5.7 olmasına karşılık, yoksulluk oranı artmış. DİE 2003 rakamlarına göre 936 bin kişi mutlak yoksul. Ekonomik büyümenin yoksulluğu azaltacağı tam bir sosyal yalan. Gıda dışı ihtiyaçlarını karşılayamayan nüfus 19 milyon sınırına dayanmış.

Klasik iktisat teorilerinden öğrendiğimiz bilgiye göre, ekonomi politikalarının ne ölçüde başarılı olduğu beş kritere göre değerlendirilir: İstikrarlı büyüme, düşük enflasyon, dış ekonomik denge, adaletli gelir dağılımı ve düşük işsizlik oranı. Bizdeki ekonomik büyümeye rağmen diğer dört gösterge hâlâ zayıf. Enflasyon tek haneli rakamlara yaklaşmasına rağmen etkileri henüz hissedilmedi. Diş ekonomik denge borçlanma lehine bir eğilim içinde. Adaletsiz gelir dağılımı değişmedi. Yüksek işsizlik oranı da ortada. Hane Halkı İş Gücü Anketi'ne göre açık işsizlik oranı 2003'te yüzde 10,5. Eksik istihdamla bu oran yüzde 15,3'e ulaşmış.

IV. Aile Şûrası'nın ana konusunun yoksulluk olarak belirlenmesi iyi fikir. Ancak, 1990'da katıldığım ilk şûradan bu yana iki şûra daha yapıldı. Yoksullukla ilgili kararlar dikkate alınarak Durum Tespiti Raporu üzerinden ülke ölçekli bir strateji ve eylem planı hazırlanabilirdi. Açıkçası bu kadar sınırlı çalışma yapılması için şûra düzenlemeye de gerek yoktu. Kamu kuruluşlarının şûra-kurultay etkinliği yarışı da kabak tadı vermeye başladı. $\mathrm{Bu}$ çalışmalar üniversitelerden talep edilmeli ve stratejik bilgi üretimine katkı sağlayıcı yöntemler tercih edilmelidir.

Gün boyu İkinci Komisyonda, yoksulluğun ekonomik, kültürel ve psikososyal yönlerini müzakere ettik. Bilgi akışı bakımından yararlı da olsa, bu müzakerelerin sonuç almaya yönelik bir işlevi olamayacak. Adı yoksulluk olan modern fili herkes, kendince tanımlama yarışına girmiş oldu. Benim modern filim mahşerin üç atlısına benziyordu: IMF, Dünya Bankası ve Dünya Ticaret Örgütü mahşerin üç atlısıdır ve dünya sisteminin bu ekonomik öznelerini doğru okuyamadan küreselleşen yoksulluğu anlayamayız. Kadim dünyada yoksulluk ferdin bire bir kendi hayatı ile ilgiliydi. 20. yüzyılın başında yoksullarla ilgili tavır alınması gerektiği savunulmuştu. Bugünkü küresel dünya ise yoksulluktan sorumlu olmadığını açıklamıştır. hem de gündem değişikliğiyle karşı karşıyayız. Ve küreselleşme sürecinin 
dünyayı çok yönlü ve hızlı biçimde kuşatması karşısında yoksulluğun yeniden tanımlanması aşamasına gelinmiş oldu. Küreselleşmenin isim babası sosyolog Roland Robertson, küreselleşmeyi “dünyanın sıkıştırılması ve bir bütün olduğu bilincinin artması" biçiminde tanımlamıştı. Malcolm Waters'ın küreselleşme vurgusu ise şöyle: Toplumsal ve kültürel düzenlemeler üzerindeki coğrafya ile ilgili sınırların ortadan kalkması süreci ve insanların da bu sürecin farkında olmaları... Notlarıma bakıyorum: Küreselleşme ekonomisi alışılmış bir ekonomi değil. Teoman Duralı'ya göre geliştirilmiş olan, alışagelinmiş iktisat modelidir: Alışagelmiş iktisatta, var olan temel ihtiyaçlara göre üretim yapılır. Geliştirilmiş iktisatta ihtiyaçlar üretilir ve tüketim kamçılanır... Bir yanda sömürgeleştirilmiş bir dünya, öbür yanda yeryüzünün tekmil nimetini devşiren bir anavatan: emperyalizm...

Türkiye, Batılılaşma süreci boyunca hemen her alanda ödünç kavramları kullanan bir ülke. Bu da bizim hemen her sorunu ödünç kavramlarla açıllamamıza neden oluyor. Türkiye, bilgi üretimi yapamayışı ve kendi modernliğini üretemeyişi nedeniyle her yeni gündem sırasında aynı kolaycılığa düşmüş oluyor. Kültürel kodlarına göre kavramlaştırma yapamadığı gibi, düşünce de üretemiyor. Küreselleşme alanındaki durum da farklı olmadı: Ödünç kavramlarla küreselleşmeye muhalefet ettik veya küreselleşme sürecini kabullendik. Ya küreselleşmenin yararlı olduğu tezini savunduk ya da toptan reddine yöneldik. Küreselleşme ve yoksulluk ilişkisini hem neden hem de imkân ve firsat olarak görenler de oldu. Tıpkı M. Chossudovsky gibi: Yoksulluğun global bir tehdit hâline gelmesi, çözümünün de küresel bağlamda ele alınmasını zorunlu kılmaktadır... Benim burada sorduğum soru ise kendi ev ödevimiz ile ilgili: Biz bu ekonomik ve kültürel yoksullaştırma kuşatmasından nasıl kurtulabiliriz? Bir, modern dünya mahşerinin üç atlısına karşı tam bağımsızlık. İki, bütün toplumda üretimin verimliliğini artırarak katılım süreçlerini yaygınlaştırmak. Bunun sonucunda şeffaflaşma ile birlikte adil ve mümkün olan eşit dağılımı sağlamaya yönelebiliriz.

\section{Ankara, 19 Mayıs 2004}

Yoksulluğun nedenlerini tartışmak. Yıllardır yapılan da bu. Hemen herkes yoksulluğu sonuçları üzerinden değerlendiriyor. Cesur, cüretkâr ve tepeden. Önleyici politikaları merkeze alan yok gibi. Orhan Türkdoğan yıllar önce Yoksulluk Kültürü'nü ilk gündeme getirenlerden biri olmuştu. Sabri Ülgener bu konuyu zihniyet ilişkisiyle açıklamıştı. Din-fakirlik ilişkisini dinin yoksulluğu tamir etme gücü ile açıklayanlar dün olduğu gibi bu gün de az 
sonucu çıarılıyor. İkinci yorum daha gerçekçi: Din, yoksulluğun ortadan kaldırılması ve önlenmesinde etkin güce sahiptir.

İlahi dinlerin hiçbirinde yoksulluğa övgü yok. Fakire yardım ise övülüyor. Dinler yoksulluğu erdem olarak açıklamadığı gibi, dindar olmanın şartı olarak da açıklamazlar. Fakirin yoksulluğa karşı direncini sağlayan temel iki kavram ise kanaat ve sabır. Yoksulluğun kabullenilişinde itaat kültürü de etkendir. Burada sorulması gereken soru şu olmalıdır: İtaat kültürü kimin işine yarıyor? Adil olmayan düzenlerin ve iktidarların. Bu noktadan hareketle iktidarların yoksulluk problemini çözmeye cesaret edemediği sonucunu çıkarmak da mümkündür.

Temel bir nokta olarak şu kaydı düşmemiz gerekir: Yoksulluğu konuşmak aynı zamanda dini konuşmaktır. Dinin de yoksulluğun da öznesi insandır. Bir insanda bütün insanlığı düşünmek ve konuşmak. İnsanlığın hâllerini düşünmek. Yoksulluğun yerine kendini koyabilmeyi öğrenmek. Paylaşmak, yoksulda kendini hissetmek: Sosyal duygu ile yoksula yani insana yönelmek. Mustafa Kutlu'nun, kulakları çınlasın: Kanaatten uzak yaşıyorsak Yoksulluk İcimizde'dir.

Türkiye nüfusunun yüzde 15 'i yoksul. Hatta açlık sınırında. Bu gerçekle yaşayan bir toplumun toplumsal psiklojisi nasıl düzgün olabilir ki! Yoksulluğun hâkim psikolojisi ise umutsuzluk üretir. Değer üretmeyen aile ortamlarında yoksulluğun eşikleri daha ağır bedellere neden olabilir. Yoksulluk gerçeği ile modern yüzyılda daha da iç içeyiz. Yaşadığımız gerçeklik de bunu bize zaman zaman hatırlatıyor. Öyle ağır örnekleri görmeye alışıyoruz ki halimizden memnun oluyoruz. Aslında bu bir ikiyüzlülük. Yoksulluğun nedenlerini dışta aramak da bir kaçıştır. Ülkenin mali ilişkilerinde belirleyici olan dış mali kaynağın ise yoksulluğu beslediği muhakkak.

Son on yılı değerlendirelim: Toplumsal masraflardan kaçınılan politikalar uygulanmıştır. Aynı zamanda toplumsal tüketim harcamaları alt düzeylere çekilmiştir. Bunun sonucunda ise özel mali sermaye birikimini destekler nitelikteki harcamaların genişlemesine yol açılmıştır. Kamu alanının ideolojik, siyasal ve ekonomik olarak yitirilmesi, toplumsal yoksullaşmanın da en önemli gerekçesini oluşturmuştur. Kürselleşmeye bağlı olarak sosyal devletin zayıflaması ve kamu alanının yoksullaşması sonucu, beraberinde mutlak ve göreceli yoksulluk artırmıştır. politikalar uygulayamadığı gibi, bu olumsuzluklar da henüz kontrol altına 
alınamamıştır. Tek parti hükümeti, psikolojik yönden güven verse de bu yeterli değil. İşsizlik probleminin çözümü de ertelenmiş görünüyor. Dahası muhafazakâr bir partinin "yardım" yaklaşımı dışında ülke ölçekli somut sosyal politikası yok. Güç koşullardaki gruplara yapılan yardımlarla yetiniliyor. Sıkı IMF politikalarının uygulanması yoksulluğu derinleştirdikçe yoksulların çaresizliği ve sarmalı daha da genişleyecek. Yoksulluğu önleyecek ekonomik, sosyal ve kültürel programların sosyal maliyetine cesaret edilmedikçe de bu alanın problemlerini kökten çözme imkânı olamayacak. Oysa 58'inci ve 59'uncu hükümetlerin oy tabanı da büyük oranda yoksul kesime dayaniyor.

Yoksulluğu tetikleyen en önemli odaklardan biri de medyadır. Medya tüketimi pompaladıkça yoksullar üzerindeki psikolojik etkileri de artıyor. $\mathrm{Bu}$ ise, hemen her gün en trajik yoksulluk hikâyelerinden birkaçına tanık olmamızı sağlıyor. Buna karşılık medya, yoksulluğun nedenlerine eğilmekten kaçınıyor. Sistemin mantığı da bu. Hiçbir iktidar iktidarını yoksullarla paylaşmayı öğrenemezse kök sorunları çözemez.

Bugün, IV. Aile Şûrası'nda hazırladığım önerileri sundum: Yoksulluğun önlenmesi amacıyla hükümet kuruluşları, yerel yönetimler ve uzman sivil toplum kuruluşlarının iş birliği ve gönüllü ortaklığının ülke ölçekli etkin biçimde gerçekleştirilmesi, bir. Yoksul nüfusun suç ve şiddet oranlarını tetikleyebileceği gerçeğinden hareketle yoksul nüfusa psiko-sosyal hizmet verilmesi, iki. Yoksul ailelerin ülke ölçekli durum tespiti yapılması, üç. Yoksulluğun çocuk üzerine etkileri konusunda ülke ölçekli çocuk yoksulluğu merkezli önleyici programların hazırlanması, dört. Ev içi üretim atölyelerinin yaygınlaştırılarak etkin yasal güvence sisteminin geliştirilmesi, beş. İşsiz genç iş gücünün üretebilir duruma getirilmesi amacıyla yoksul bölgelere yönelik Hükümet Kuruluşları ve özel sektör iş birliğinde istihdam projelerinin özendirilmesi, altı. Göstergeleri yoksul olan nüfusa vergi muafiyetinin sağlanması, yedi. Yoksul nüfusun gelişme, kültürel ve sosyal haklarının yerine getirilmesi amacıyla ülke ölçekli ve erişilebilir hizmet projelerinin yaygınlaştırılması, sekiz. Yoksulluğun çocuk hakları ihlali ve çocuk ihmali ve istismarını yaygınlaştırdığı dikkate alınarak, rehabilitasyon, psikolojik danışmanlık ve eğitim hizmetlerinin yerel yönetimler ve uzman sivil toplum kuruluşlarının öncülügüünde gerçekleştirilmesi, dokuz. Yoksulluğun azaltılmasına yönelik yasal düzenleme yapılarak hizmet, eğitim ve araştırma projelerinin uygulanması, on. Ulusal ve uluslararası medyanın tüketim kültürünü yaygınlaştırmasındaki rolü ve etkilerine yönelik önleyici, bilinç oluşturucu ve uygulanabilir etkin izleme çalışmalarının yapılması, on bir. 
Çocuk Vakfı'nın önerisi olan Aile ve Çocuk Müsteşarlı̆̆ ile Aile ve Çocuk Bakanlığı'nın kurulmasını yarın tekrar önereceğim.

\section{Ankara, 20 Mayıs 2004}

IV. Aile Şûrası Genel Kurulu, altı komisyon raporunun müzakere edilmesi ve alınan birkaç kararla sona erdi. Öncekilerden tek farkı yoksulluk üzerine yoğunlaşmış ilk şûra olmasıydı. Öncekilerle benzerliği ise yine fili tarifle yetinmesiydi. İlk komisyon konusunun Yoksullukla Mücadele Stratejileri ve Acil Destek Programları olduğu hâlde, raporu stratejik bilgiden yoksundu. Türkiye'nin en acil ihtiyacı olan strateji geliştirilmedikçe filin çevresinde dönüp duracağız. Ana soru şu olmalıdır: Yoksulluğun önlenmesiyle ilgili belirleyici temel politika ne olmalı?

Gelir merkezli yaklaşım, mutlak yoksulluk veya gelir yoksulluğu anlayışının egemenliğini sürdürmesine, ihtiyaç merkezli yeni bakış açısı ise göreli ve insanî yoksulluk kavramlarının açılımına neden olmuştur. Yoksullukla mücadele stratejisinde, ihtiyaç merkezli yaklaşımdan hareketle programlar geliştirilmelidir. İnsanı yalnızca biyolojik varlık görme anlayışı yerine, göreli yoksullukta olduğu gibi, insanı sosyal bir varlık kabul etme anlayışı ile stratejinin ana ekseni paralel duruma getirilmelidir. Yoksulluğun ölçülmesinde, gelir dağılımı yoksulluğu kavramından, insanî yoksulluk kavramına, tek boyutlu yoksulluk tanımlarından bileşik endekslere doğru bir geçiş olduğu da dikkatten uzak tutulmamalıdır.

İnsanî Yoksulluk Endeksi, yoksulluğun gelir dışındaki farklı boyutlarını dikkate alan (hayatta kalma, eğitim, sağlıklı suya ulaşma vd.) bir birleşik endeks olarak UNDP tarafından önerilmiş ve yaygın biçimde uygulandığı hâlde, bu yaklaşım fotoğraf çekmekten öte bir işe yaramıyor. Yeni bin yılın kalkınma hedefleri arasında yer alan günlük ortalama geliri 1 doların altında olan nüfusun oranı ve göstergesi gelir yoksulluğunu ölçmeye yarıyor. Dünya nüfusunun beşte biri 1 doların, yarısı ise 2 doların altında gelir elde etmektedir. Bu rakamlar da dünya ölçekli fil tanımı yapmaya yetmiyor. Türkiye'nin yüzde 15'i göreli yoksul. Yüzde 1.6'sı gıda yoksulu-açlık sınırı altında. Yüzde 27'si gıda ve gıda dışı ihtiyaçlarını elde edemiyor (DİE Hane Halkı İş Gücü anketi 2003). Gelir dağılımına göre değil ihtiyaç merkezli, insanı sosyal varlık olma özelliğine göre kabul eden ve onu güvencelerine kavuşturan ana felsefe merkeze alınarak strateji geliştirilmelidir.

Türkiye nüfusunun yüzde 66.2'sinin şehirlerde yaşadığı dikkate alınırsa, yoksulluk stratejilerinin çok yönlü ve boyutlu olduğu daha kolay 2021/1 kavranabilir. IV. Aile Şûrası'nın Kent Yoksulluğu Komisyonu Raporu bu yönü ile tanımlayıcı bir çalışma oldu. Birinci tanımlamaya göre kent 
yoksulluğu sekiz basamaktan oluşan bir piramitten oluşmaktır: Yetersiz gelir. Yetersiz ve istikrarsız kaynak (servet) sahipliği. Yetersiz barınma. Kamusal altyapı hizmetlerinin yetersizliği. Sosyal güvenlikten mahrumiyet. Yoksulların hukuk sisteminin işleyiş sürecinde yeterince korunamaması. Yoksul kesimlerin karar alma süreçlerindeki etkisizliği, güçsüzlüğü. Yoksul kesimlerin sessizliği. İkinci tanımda kent yoksulluğu, ekonomik bir sorun olmanın yanı sıra, geniş kapsamlı üç temel bileşenden oluşmaktadır: Bireysel gelişim, fiziksel koşullar ve toplumsal ilişkiler. Bireysel gelişimin alt bileşenleri gelir, eğitim, sağlık ve güvenliktir. Fiziksel koşulların alt başlıkları konut, kentsel alt yapı ve doğal çevredir. Toplumsal ilişkilerin alt bileşenleriyse aile, enformel örgütlenmeler, siyasal partiler, sivil toplum kuruluşları ve cemaat ilişkileri.

Şûra boyunca köy yoksulluğunu çok az konuşabildik. Avrupa Birliği sürecine yönelik altıncı komisyon raporu ise bu sürecin kültürel ve sosyal yönleri üzerinde durulmadığını belgelemiş oldu.

Aile ve Çocuk Bakanlığı'nın kurulması yönünde Başbakan Recep Tayip Erdoğan'a yaptığımız çağrı da Ankara'da henüz duyulmadı. Aradan 18 ay geçmesine rağmen Hükümetin bu alana yönelik temel politikası da hâlâ oluşmadı. Maliyeti nedeniyle âdeta "yardım” dışındaki sosyal politikalardan kaçınılıyor. Hükümete ürkeklik hakim. Hükümeti bu durumdan çıkarmak ve etkilemek amacı ile her dört şûranın Durum Tespiti Raporları dikkate alınarak, önerilerin tematik sıralamasının yapılması, ülke ölçekli programın geliştirilmesi, hizmet, eğitim, araştırma ana başlıkları altında Aile ve Sosyal Programı'nın oluşturulması ve çalışmaların hükümet kuruluşları, yerel yönetimler, özel sektör ve uzman gönüllü sivil toplum kuruluşlarının iş birliğinde gerçekleştirilmesini önerdim ve kabul edildi. Genel Kurul'un tek kararı da bu oldu. Bakalım iktidar yoksullarla iktidarını bölüşmeye cesaret edebilecek mi?

\section{Tarabya, 8 Ocak 2005}

Çocuğu ve yaşlıyı ortada bırakmayan kültür geleneğinden uzaklaştıkça, çocuğu da yaşlıyı da ortada bıraktık. Bütün bir toplumda bu kadim geleneğe dayalı tavrı geliştirmemiz gerekecek. Evet, ama nasıl?

\section{Nişantaşı, 17 Şubat 2005}

Çocuk işçiliği, işsizliğin, eğitimsizliğin, yoksulluğun, nüfus artışının ve ekonomik krizlerin sonucudur. Çocuk hâlâ ülkemizde ekonomik değer olarak algılanıyor. Anne-baba işsiz ya da sürekli ve güvenceli iş ortamlarında çalışmıyorsa çocuklar daha kolay devreye sokuluyor. Aile çevresi ekonomik, 
sosyal ve kültürel yönden olumsuz ortamlardan oluşuyorsa çoğu iş gücü istismarının farkına varılmıyor.

Zorunlu eğitimin sekiz yıla çıkarılması okul çağı nüfusunu artıracak. Çalışan çocuk nüfusunda azalma sağlanacak mı? Eğitimsiz oldukları için meslek gerektirmeyen iş kollarında çalışıyor çocuklar. Beş çocuktan birinin çalışmaya mecbur kalması gelecek bakımından da çok sorunlu bir halka demektir. $\mathrm{AB}$ sürecinde tarımda daralmaya gidilirse nüfus, şehirlerde yoğunlaşacak. Bu aşamada ise kent çocuk işçiliğini azaltacak sosyal programların uygulanması gerekecek.

\section{Tarabya, 16 Haziran 2005}

Çeyrek yüzyılı, havuzdan taşan çocukları konuşarak geçirdik. Havuzdan taşanları halının altına süpürdüğümüzü de yeni fark ettik. Doğru bilgi, doğru soru ve doğru eylemle çıkmaya cesaret edemedik. Bugün de sokaktaki çocuklarla yüzleşmeye ne kadar hazır olduğumuz tartışılır.

SHÇEK'in Sokakta Yaşayan ve Sokakta Çalıştırılan Çocuklara Yönelik Hizmet Modeli için düzenlediği ve bugün başlayan toplantı, büyük ölçüde, ben devletim çözerim, mantığının hakim olduğu anlayışla gerçekleşti. Bütün resmi aktörlere yer verildiği halde toplumun katılımı öngörülmedi. Tipik bir Ankara boyalı yaklaşım. Daha da ilginci iktidar partisinin yerel yönetimleri toplantıya çağrılmamış. Sokakta yaşayan ve çalıştırılan çocuklarla ilgili toplumsal şefkat de yetmez. Sokaklardan umuda yolculuğa çıkmak için kıyıya vuran çocuklarımızın dilini ve gerçeğini öğrenmekle işe başlamalıyız. Denizyıldızlarını dinlemeden önce denize girmeye ve ıslanmaya karar verdiğimizde çözümün parçası olabiliriz. Çözümün parçası olmak ise, çocuğun safında olduğumuzun fark edilmesi anlamına gelir. Çocuğun çözüme katkı vermesi de bu noktadan başlayabilir. Her denizyıldızının öyküsü farklı olsa da, onları kıyıya atan bir dalga vardır. Dalganın şiddeti ve boyu bilinmeden geri dönüşün ne zamanı ne de hızı bilinebilir.

Denizyıldızının ailesinden kopuşunu bilmek, dönüş yolculuğunun da yol haritasıdır.

Çocuk ve Gençlere Yönelik Önleyici ve Koruyucu Sistem olmadan sonuçlarla ilgilenmeyi sürdüreceğiz. Sorunun kaynağı da çözüm yeri de öncelikle ailedir. Ailenin değer üretimi, sosyal güvenliği, erken çocukluk dönemi eğitimi, çocuk refahı, çocuk yoksulluğunu merkeze alan çocuk politikası ile havuzun taşması azalabilir.

Denizyıldızı deyince, yolculuğa çıkmayı düşünmüşüm hep. Islanmadan yüzülemeyeceği gibi denizyıldızlarına eğilmeden de yolculuk başlayamaz. 


\section{Tarabya, 17 Haziran 2005}

Dün başlayan toplantı nedeniyle hayaller ve gerçekler karşısında insanların halleri üzerinde biraz olsun düşündüm. Hayallerden vazgeçenler mi daha çoktur, gerçeklerden vazgeçenler mi? Hayallerden de gerçeklerden de vazgeçenleri tanıdım. Ne hayallerden ne de gerçeklerden vazgeçenlerle yürümeyi tercih ettim. Hayalleri daha önde olanlarla konuşmak daha huzur verici.

Denizyıldızlarını konuşacağımız ortak dilimiz yok. Gerçekliklerini öğrenmek, onları duymamıza, dinlememize ve hissetmemize bağlıdır. Sorunu ancak böyle yakından görebiliriz.

Devletin gözleri politikacılardır. Yıllardır, sokakta yaşayan çocuk konusu güç koşullardaki çocukların ilk gündemini oluşturuyor. Dahası bu çocuk gündemi diğer çocuk sorunlarını da örten bir sarmala dönüşmüş durumdadır. Dün sunumu yapılan çalışma ile önerilen çözüm yine devlet merkezli. Hükümet kuruluşları ve kısmen yerel yönetimlerin içinde yer alacağı bu yaklaşımla sonuç alınması imkânsız. Çalışan çocuklarla sokak çocukları hizmet modeli farklı olması gerekirken, modelin başlığında karmaşa hâkim. Önce sokakta yaşayan çocuk gerçeğini stratejik bilgiye dayalı olarak öğrenmeliydik. Buna dayalı olarak ana projenin esaslarını, standartlarını, izleme-denetim ilkelerini de belirlemeliydik. Önerilen taslak hizmet, eğitim ve araştırma yönü bütünlük içermiyor. Sürdürülebilir olmadığı gibi katılıma da çok sınırlı ve küçük bir pencere aralıyor. İş birliği tanımlanmamış.

Çocuk ve Gençlere Yönelik Önleyici ve Koruyucu Sistem kurulmadan havuz taşacak ve dalgaların boyu da uzayacak. Sosyal yatırım öncelikli politikalar yanında aileyi güçlendirici politikaların da geliştirilmesi gerekir. İstanbul dışındaki şehirlerde geliştirilen modeller daha gerçekçi ve toplumun katılımına daha açık. Ne yazık ki, devlet gücüne sığınarak çözüme gidileceğinde inat ediyorlar. Bu kafayla bu çocuk cangılındaki kargaşa bitmez. İlgili yeni Bakan Nimet Çubukçu’ya, görüşme isteği, üzerine yangının nasıl sönebileceğini anlattım. Dinlemekle yetindi. İkinci kez görüşeceğimizi de sanmıyorum.

\section{Tarabya, 29 Temmuz 2005}

Yirmi metre uzunluğunda karşılıklı oturma düzenine göre yemek masası. Korumaya muhtaç çocukları konuşacağız. 2828 SHÇEK yasasında, bu ay yapılan düzenlemeyle korumaya muhtaç çocuklara bakma tekelini savunanlar ve kaldırılmasını isteyenlerin aynı masa etrafında toplanması 
ilginç. Korunmaya muhtaç çocuklarla ilgili vakıf ve dernek kurmaya yönelen muhafazakârlar hazırlık yapıyor. SHÇEK Genel Müdürü İsmail Barış’a bu sürecin yeni bir yanlışın başlangıcı da olabileceğini söyledim. Kamu velayeti hangi kurum üzerinden yürütülecek? Bu mesele de Çocuk Koruma Kanunu ile ilgili. Her yanlışı parçalar üzerinden düzeltme alışkanlığı devam ediyor. Bakan Nimet Çubukçu, henüz önünü görmüş izlenimi vermedi bana. İkinci karşılaşmamızda susmayı tercih etmem iyi oldu. İşin esasını konuşunca muhalif olarak algılanıyor insan.

Yusuf Ahmet Kulca, Dağlarca'yla tanışmadığını söyleyince Dağlarca'yı aradım ve Kadıköy'deki evinde ziyarete gittik. Dağlarca, su kaybı nedeniyle bir hafta hastanede kalmış. İyisin deyince, yüzüm tiyatro oynuyor, dedi ve güldü. Yusuf Ahmet'in Dağlarca ile ilk karşılaşması. İkimiz de çocukların safında yürüyen delileriz, ne önerirsin bize, diye sordum. Dört cümle sıraladı hemen; İçtenliğimizi yitirmeyelim. Hiç bir siyasi tavır sizi engellemesin. Uygarlığın bir ulus için ekmek olduğunu unutmayın. İnsan yeryüzünde bir tek insandır. Dağlarca, Yusuf Ahmet'le ikimizin de hiç parası olmadığını öğrenince sert bir üslupla şöyle dedi: Çocuğun parası olmaz, parası olan çocuktan uzaktır. Ve ardından, kuracağı vakfı konuştuk. Akranlarının öldüğünü ve güvendiği kimsenin kalmadığını söyledi. Yaşlılardan en çok duyduğum cümle de bu. Fotoğrafı çekilirken Dağlarca'yı bugünkü kadar istekli görmedim. Yusuf Ahmet'in çektiği gözlüksüz ve gözlüklü ikili, üçlü fotoğrafların akıbetini merakla bekliyorum.

\section{Nişantaşı, 10 Ekim 2005}

Malatya Çocuk Yuvası'nda dövülen çocukların görüntüleri 8 Ekim'den bu yana televizyonlarda yayınlanıyor. Gazeteler bu haberi birinci sayfalarından verdiği için televizyonların görüntü yarışı ve haber-tartışma programlarında çocuklar unutulmuş; söylem, hükümet eleştirisine dönüşmüş. Daha da can sıkıcı olanı ise iktidarı destekleyen 'muhafazakâr medya'nın acemice iktidarı savunması. Eski SHÇEK Genel Müdürü İ. Melik Gökçek'in aile ve çocuktan sorumlu Bakan Nimet Çubukçu'yu savunması ise hiç şı olmamış. İktidarı destekleyen medyadan görüş istenmesine rağmen görüş bildirmedim. Çocuk yerine iktidarı savunanlarla hiçbir zaman yollarım örtüşmedi ve yaşadıkça da örtüşmeyecek. Yaptığım açıklamaya ise özellikle 'muhafazakâr medya' yer vermedi. Tarihe kayıt düşmek için bu kısa paragrafı günlüğüme alıyorum:

\section{Çocukların Malatya'dan Türkiye'ye Attığı Tokat}

Türkiye'de hiçbir iktidarın önceliği çocuklar ve yoksulluk olmamıştır. Politika bekleyebilir, politikacıların çocuklardan ve yoksullardan beklemelerini isteme hakları yoktur. 
Politikacıların öncelikli görevi sorun çözme yeteneğini kullanarak çocuklar ve yoksullar üzerindeki suskunluk sarmalın kaldırmaya yönelmektir. Son beş yılda çocuklar ve yoksullar ekonomik krize mahkûm edilmiştir. Bunun sonucu olarak, güç koşullardaki çocuklara yönelik değer üretimine odaklı sosyal politikalar ekonomik politikalarla paralel sürdürülememiştir. Malatya'daki yuvadan çocukların Türkiye'ye attığı tokadı ve Erzurum'da yuvada ölen bebeğin buz kesmiş bedenini kucağımızda hissetmedikçe bu trajik uyarı fark edilmemiş olacaktır.

\section{İstanbul, 7 Kasım 2004}

MCLuhann'ın “Mesaj aracın kendisidir” aforizması, iletişimin amentüsü olalı, bu sözün eşiğinden geçmeden fikirler sarmalı açılamıyor. Postman da, "Medya kendi şeklini ve içeriğini iletir" açılımıyla mesaj-medya ilişkisine katkı vermişti. Medyanın özel mesajları doğru biçimde iletemeyeceğini savunuyorum. Medya, kutsalın dile özel bir anlatımını kullanmadıkça kutsalı doğru yansıtmaz ve sanallaştırır. Özel iletiler ise sahihliğin yansımadığı bir dille mümkün olamaz.

Dünya Değerler Araştırması'nda (2000) 43 ülke arasında Türkiye en sonda. Türkiye, sadece yüzde 6,5'u birbirine güven duyan bir ülke. Bu orana kuşkuyla bakıyorum. Ancak, Aile Şûralarında, değer üretiminin zayıfladığı, üretilmiş değerlerin tüketimine yönelişin hızlandığı bir sürecin yaşandığı yönünde bir kanaat ortaya çıkmıştı.

Değer ve güven ilişkisinde en belirleyici öznenin din olduğunu düşünüyorum. II. Uluslararası Dinî Yayınlar Kongresi öncesinde ana sorum şuydu: Medya dini anlatmaya ehil midir? Kongre sonrası kanaatim şu oldu: Medya, kaynağının dilini dönüştürmeden, dinin doğasına uygun ve doğru anlatılması mümkün değildir. Seyed Hassan Hosseini, ne tamamen kabul ne de tamamen ret yaklaşımını yorumladı. İletişim dünyasında kabulcülerin de retçilerin de referansları yine Batı'dan.

\section{Tarabya, 2 Aralık 2005}

İstanbul'da düzenlenen Uluslararası Aile Sempozyumu'nun ilk gününde Ahmet Emre Bilgili'nin Ailesizlik: Sokağın Çocukları bildirisini Yusuf Ahmet Kulca ile değerlendirdik. Yusuf Ahmet'in havuz ve dört musluk yorumunu aynı heyecanla anlatması hâlâ bir şey yapılamadı̆̆ının da tescili gibi. Toplumda çözümsüzlük duygusunun hakim olmasının birçok nedeni sıralanabilir.

Çocuk ve Medeniyet 2021/1 Sokağın çocukları konusunun, diğer çocuk sorunlarını örten sarmal gibi, acıtıcı bir sarmala dönüşmesi de garip bir çocuk gerçeği durumudur. Oturumun Başkanı Esin Küntay Hoca ile aynı nokta üzerinde durduk: Aile 
ve çocuk politikasında anlayış değişikliğine gidilmesi ve güç koşullardaki ailenin desteklenmesi için strateji hazırlanması gerekecek.

\section{Nişantaş1, 29 Eyluil 2006}

Türkiye'nin Çocuk Karnesi-Ekim 2006 raporunu bugün açıkladık. Bardağın dolu ve boş tarafını göstermek hiç de kolay olmadı. Raporun sonunda boş olan kısmın nasıl doldurulacağı için de öneriler yer aldı. Ülkeyi yöneten siyasi heyet, karneyi eleştiri ve muhalefet biçiminde algılayacak. Son dört yıldaki karneden rahatsız olmaları doğal. Seçim eşiğinde, karne sözcüğü bile tek başına muhalif olmaya yetiyor.

Başbakan Recep Tayip Erdoğan'a, Mayıs 2003'te arzusu üzerine hazırladığımız Türkiye'nin Öncelikli Aile ve Çocuk Faaliyet Planı'nın dosyasını sunmuştum. Başbakanlığının ikinci ayıydı. Ne yazık ki iki görüşme dışında bu konuları bir daha konuşamadık. Başbakanla o günlerde tanıştırdığım Nesrin Avşar Çelik Aile Araştırma Kurumu'na, Mehmet Aysoy Özürlüler İdaresi Başkanlığı'na vekaleten atanmıştı. Atanan Aile ve Kadınla ilgili Bakanlar ülke ölçekli hiç bir politika üretemediler. 1990'larda hazırlanmaya başlanan Özürlüler Kanunu'nun yasalaşması ise bu dönemde en önemli kazanç oldu. Yönetilemeyen SHÇEK iyice açmaza girdi. Yuva, yetiştirme yurdu ve huzurevlerinin yerel yönetimlere devri sağlanamadı. Bir yönetmelik değişikliğiyle derneklere ve vakıflara çocuk bakım yetkisi verilerek adeta bu yük, ihtisası olmayan ve çoğu yeni kurulmuş derneklerin cılız omuzlarına terk edilmek istendi. Güç koşullardaki nüfus için aile odaklı öngörüde bulunulamadı ve yoksulluk biraz daha derinleşti. Muhafazakârların yardım dağıtma anlayışı bu dönemde daha da yaygınlaştı.

Son dört yılda eğitim yönetimi hiç güven vermedi. Müfredat yenileme çalışmaları bile anlatılamadı. Hüseyin Çelik'in kavgacı üslûbu yapılan iyi şeylerin de üstünü örttü. Eğitim yönetiminin Türkiye’ye yakışmadığını iktidar çevresi de kabul etti ama Tayyip Bey'in ısrarı devam etti. Bu dönemde Türkiye, Bakanların inisiyatif kullanamadığı Hükümet üslûbuyla tanıştı. Yoksulluk ertelendi. Güç koşullardaki çocukların hiçbir kök sorunu çözülemedi. Sosyal güvenliğin tek şemsiye altında toplanması çalışmaları da sonuçlanmadı. İktidar, çevreden merkeze yerleşmeye ağırlık verince iktidarını yoksullarla paylaşmaktan uzaklaştı. Ne yapalım, kendi düşen ağlamaz! Çocuk karnesi biraz da bunları hatırlatmak içindi.

171

Çocuk ve Medeniyet 2021/1

\section{Nişantaşı, 21 Ağustos 2007}

81 il ve 957 ilçede örgütlenecek icracı Aile ve Çocuk Bakanlığı'nın kurulması için bir kez daha Başbakan Recep Tayyip Erdoğan'a mektup gönderdim. 
Başbakanlık Müsteşarı Ömer Dinçer'le yaptığımız ilk telefon konuşmasında Müsteşarlık kurulmasını gerekli görmediğini söyledi. Böylece, Aile, Çocuk ve Sosyal İşler Müsteşarlığı raporumuz da sümen altı edilmiş oldu.

\section{Nişantaşı, 1 Kasım 2009}

Spordan sorumlu Devlet Bakanlığı'nın hazırladığı Ulusal Gençlik Politikası Hazırlık Raporu ulaştı bize. Bu rapor, yedi yılda gençlikle ilgili yapılan en kapsamlı (!) ön çalışma. Yalnızca, bilgi içeriyor. Hazırlanma gerekçesi de yok. İktidar partisi çocuk ve gençlik konusunda ne sosyal ne de kültürel program hazırlayabildi. Ufukta bir öngörüsü de yok...

\section{Tarabya, 9 May1s 2010}

Çocuk yoksulluğu ile Çocuk hakları arasındaki birebir ilişkiyi nasıl yorumlamalı? Yoksulluk, düşük hane halkı geliri ve tüketim düzeyleri gibi maddi göstergelerle ölçülebiliyor. Yoksulluğu etkileyen sağlık, eğitim, konut, aile büyüklüğü ve sosyal koruma olup olmaması yoksulluğun çocuklar üzerindeki etkilerinin tespitinde önemlidir. Bu konuda uzun zamandır zihnimi kurcalayan soru ise daha farklı: Yoksulluğun çocuğun psikolojik, fizikî ve zihnî gelişimi üzerindeki etkilerini bütün boyutlarıyla ölçebilir miyiz? Dünyada henüz bu yönde ölçme ve değerlendirme ölçütleri belirlenemedi. Yoksul çocukların içinde bulunduğu güç koşulları sıralamak gerekirse şu başlıkları not edebiliriz: Yaygın ihmal ve istismar, bir. Sağlıklı büyümeme ve sağlığını koruyamama, iki. Eğitimden yararlanamama ve zayıf eğitim durumu, üç. Küçük yaşta iş gücü olarak kullanılma, dört. Küçük yaşta evlendirilme ve hamile kalma, beş. Suç işleme eğilimi ve antisosyal davranış, altı. Madde bağımlılığı, yedi. Uzun süre devlet yardımına bağımlı kalma, sekiz. Ülkenin işsizlik durumu, dokuz.

Çocuk yoksulluğunu ele almak ve üzerinde düşünmek bu olumsuzlukları ortadan kaldırmaya yönelmek anlamını da içerir... Dünyanın yaman hallerine akıl erdiremiyoruz.

UNICEF'in Zengin Ülkelerde Çocuk Yoksulluğu, 2005 raporuna göre, Ekonomik İş birliği ve Kalkınma Örgütü'ne üye 24 devletten 17'sinde yoksulluk içinde yaşayan çocuk oranında artış olmuş. Rapor, çocuk yoksulluğu düzeylerini üç faktörün birleşimi ile belirlemiş: Ebeveynlerin yaşı, eğitim düzeyleri, aile başına düşen çocuk sayısı ve yalnız ebeveynlik gibi sosyal ve ailevi değişkenler, bir. Ekonomik durgunluk, teknolojik yenilik, düşük vasıflı işçilerin göçü, az ücretli işler, çift gelire sahip hane halkları ile birlikte özelleştirme ve küreselleşme trendleri gibi iş 
gücü piyasası faktörleri, iki. Hükümetlerin politikalarındaki ve harcama önceliklerindeki değişiklikler, üç.

Çocuk yoksulluğundaki en büyük dalgalanma ise hükümet politikalarındaki değişikliklerden kaynaklanıyor. Ortak kabullerden biri ise şudur: Devletin ailenin refah standardını iyileştirmeye ayırdığı Gayri Safi Yurt İçi Hasıla oranı ne kadar büyükse, çocukların yoksulluk içinde büyümek zorunda kalma riski de o kadar düşüktür. GSYH' sının \%10'u veya daha fazlasını sosyal harcamalara ayıran OECD ülkelerinin her birinde çocuk yoksulluğu oranı \%10'un üstünde; GSYH'sının \%5'inden azını bu tür yardımlara ayıran ülkelerin hiç birinde çocuk yoksulluğu oranı \%15'in altında değildir.

UNICEF'in öngörüsü ise şöyle: İş gücü piyasası koşullarının ve sosyal değişikliklerin gücü kabul edilse de, çocuk yoksulluğu oranlarını aşağıya çekmek Hükümetlerin yapabileceği bir şeydir...

Türkiye'nin çocuk yoksulluğu fotoğrafına daha yakından bakmaya çalıştığımızda, gördüğümüz gerçek hiç şaşırtıcı değildir: Türkiye, sosyal harcamalara ayrılan payı giderek azalan bir ülke. Ekonomik büyüme ve gelişme ile sosyal gelişme at başı bir seyir içinde olmadıkça bu uçurum genişleyerek devam edecektir.

Türkiye'nin en önemli çocuk gerçeği ise demografik gruplar içinde yoksulluk oranı en yüksek olan grubun çocuklardan oluşmakta olmasıdır. Ailedeki çocuk sayısı arttıkça hane halkı yoksulluk oranı da yükselmeye devam etmektedir. Yoksulluk oranı yükselen ailelerin çocuk iş gücünden yararlanmaya yönelmeleri de kaçınılmaz bir sonuçtur. Düşük eğitim düzeyinin de çocuk yoksulluğuyla bire bir ilişkisi vardır. Yoksulluk sağlık, eğitim, barınma ve çocuk işçiliğini etkilediği gibi, çocuk ihmali ve istismarında da en belirleyici odaklarından biri olmaktadır.

Türkiye, son 5 yılda sosyal harcamalara ayırdığı payı yükselttiği hâlde yoksulluğun önlenmesinde neden iyileşme beklenen hedeflere ulaşmamıştır? Sosyal harcamaların çoğunluğu kamu finansmanından, kalanı ise özel finansmandan harcanmaktadır. Daha açık ifade ile söylemek gerekirse, Türkiye'nin sağlık ve sosyal koruma giderlerine ayırdığı kamu finansmanı daha düşük düzeydedir. Çocuk yoksulluğu özelinde şartlı nakit transferleri, bir defaya mahsus yoksulluğu hafifletme yardımları, tarım sübvansiyonları gibi uygulamalar yapılsa da bu sosyal güvenlik tedbirleri çocuklara ulaşmadan tüketilmektedir.

Cumhuriyet hükümetleri içinde sağlık bakımından çocuğa yönelik güvence yasasını 60'ıncı Hükümet yasalaştırdı: Ailesi sosyal güvenceden mahrum 18 yaşın altındaki her çocuğu sağlık güvencesine kavuşturan bu yasa, çocuk 
yüzlü bir devrimdir. Ancak, Hükümetin henüz çocuk yoksulluğunun yapısal sorunlarını kökten çözecek ne öngörüsü ne de cesareti vardır.

Bir ülkenin çocuklarının psikolojik, fizikî ve zihnî gelişmeleri insanî gelişim düzeyiyle birebir ilişkilidir. Çocuk yoksulluğunu tanımlama ve ölçebilme potansiyeli, öngörülecek stratejinin ilgili bütün alanlarda eş güdümlü ve eş zamanlı uygulamasını gerektirir. Çocuk yoksulluğunun mali bütçeden direkt etkilendiği unutulmadan, çocuğun öncelikli yüksek yararına dayalı sosyal programı aksatmadan sonuç alma ihtimali ise çok zayıftır...

\section{Tarabya, 10 Mayıs 2010}

Yoksulların hatırı için 2010 Avrupa Yoksulluk ve Sosyal Dışlanma ile Mücadele Yılı Toplantısı' nı yönetmek üzere, sabahın erken saatinde Taksim'e gittim. Kanunla ihtilafa düşen çocuklar ve yoksulluk ilişkisi bağlamında önce Emine Akyüz Hoca'mızı dinledik. Nermin Akyıl, Sosyal Yardımlaşma ve Dayanışma Vakfı'nın yaptıklarını "icraatın içinden” programı gibi anlattı. Özürlüler İdaresi Başkanlığı temsilcisi Tayyar Kuz, engellilerin dışlanma nedenlerini yorumladı. Ceren Seda Erdem, yapısal yönüne değinmeden Çalışma ve Sosyal Güvenlik Bakanlığı'nın yoksulların sosyal güvence boyutunu anlattı. Hükümet tarafını dinleyince insanın aklı iyice karışıyor: O hâlde bu ülkede yoksullar niçin azalmıyor? Sorusunu sormadan edemiyor insan. Meğer ders kitapları da Fak-Fuk-Fon'dan karşılanıyormuş!

Günlüklerime 2005'te yoksullukla ilgili düştügüum notlar hâlâ geçerli. Bugün ülkeyi yöneten siyasi heyetin sosyal politika anlayışı "yardım dağıtma" ağırlıklı. Sonuç olarak, yoksulluk derinleşiyor. Son yıllarda ise çocuk yoksulluğu sarmalı iyice derinleşiyor.

\section{Tarabya, 9 Aralık 2010}

8 yıl aradan sonra Başbakan Recep Tayyip Erdoğan'la Haliç Kongre Merkezi'ndeki çalışma odasında, bugün öğle saatlerinde görüştük. 8 yıl içinde yaptığımız görüşme taleplerine rağmen görüşememiştik. Hemen her yıl bir ya da iki defa özel kalemine bilgi notu bıraktığım hâlde görüşmemiz mümkün olmamıştı. Her görüşme talebim ülkenin bir meselesiyle ilgiliydi. İlk sıradakiler 23-25 Eylül 2004'te himayelerinde düzenlediğimiz I. Türkiye Üstün Yetenekli Çocuklar Kongresi, Aile ve Çocuk Bakanlı̆̆ı'nın kurulması, Çocuk Adalet Sistemi ve 100 Temel Eser uygulaması konularıydı. Yarım saati aşkın sürede bu konuları değerlendirdik. Başbakanımız, kongre kararlarından biri olan Türkiye Yetenekleri Geliştirme Kurumu'nun kurulması yönünde irade beyan etti. Aile ve Çocuk Bakanlı̆̆ı'na önce itiraz etti; “mevcut birimlerin başında çalışkan genel müdürler olsa Bakanlığa gerek olmadığı” yönünde 
açıklamalarda bulundu. Genel bir izahtan sonra niçin icracı bir Bakanlığın kurulması gerektiğini tekrar izah etme ihtiyacı hissettim. Seçimden sonra Devlet Bakanlıkları'nın kaldırılacağını ve aile merkezli bir Bakanlığın bu dönemde gündeme alabileceklerini ifade ettiler.

\section{Tarabya, 16 Nisan 2011}

Öğle saatlerinde Çemberlitaş'taki Birlik Vakfi'na gecikmeyle ulaşabildim. Bahar havası insanları evlerinden çıkarmış. İstanbul'u bu kadar kalabalık görmemiştim. 1970'li yılların başından beri İstanbul'u tanımaya çalışsam ve sevsem de İstanbullu sayılmam. Orta yaşın üstünde bir gruba Medeniyet ve Çocuk konulu bir konuşma yaptım. Medeniyetimizin üç yüz yıllık krizine de değindim, kısaca. Medeniyet insanı yetiştirme idealinin uzağına düştüğümüzü yorumladım. Eski Kültür Bakanlarımızdan İsmail Kahraman Bey de teşrif etmişti. Resul Tosun Bey'in takdimini dinlerken de yaşlandığımı hissettim.

İkindi sularında Türk Edebiyatı Vakfı'na Beşir Ayvazoğlu'na uğradım. Beşir Bey'le otuz beş yıllık bir dostluğumuz var. Son kitabı, Malik Aksel Evimizin Ressamı biyografisi ile Aksel'in üç ciltlik külliyatını hediye etti. Türk Edebiyatı Vakfı'nın kullanımında olan sıbyan mektebinin tadilatının tamamlanmış olmasına da sevindim. Merdivenler $3 \mathrm{~cm}$ yükseltilmiş, yetişkin merdivenlerine dönüştürülmüş...

Akşam saatlerinde eşimle İz Yayıncılık'a uğradık. İçimde kitap yayımlama heyecanı da kalmadı. İlk kitabım 1983'ün bahar aylarından birinde yayımlandığında Cağaloğlu'ndan Merter'e kanatlanıp uçmuştum sanki... Hatıralarımı yazmak mümkün olabilecek mi? Belki de asıl eserim hatıralarımı yazacağım kitap olacak... Cağaloğlu'na gelip de Sezai Karakoç Bey'e uğrayamadığım nadir günlerden biri daha geride kaldı...

\section{Güre, 1 Temmuz 2011}

Bugün 61. T.C. Hükümeti kuruldu. 1992'den bu yana kurulmasını önerdiğimiz Aile ve Çocuk Bakanlığı, Aile ve Sosyal Politikalar Bakanlığı adıyla kuruldu. Başbakan Recep Tayyip Erdoğan'la 9 Aralık 2010 tarihinde yaptığımız 40 dakikalık ikili görüşmenin yarısını bu konuya ayırmıştık. Kurulan Bakanlığın ilk Bakanı Fatma Şahin. Parti içinde kadın ve çocuk konularıyla ilgili bir isim. Bakanlığın henüz yasası yok. Kanun Hükmünde Kararnameyle icraata başlayacak. Sosyal yardımları koordine edecek bir Bakanlığın kurulduğu anlaşılıyor. Ana soru şudur: Bakanlık 81 il 957 ilçede icracı bir Bakanlığa dönüşebilecek mi? 


\section{Güre, 8 Temmuz 2011}

61. Hükümetin Programı Başbakan Recep Tayyip Erdoğan tarafından TBMM'de okundu. Başbakan, Aile ve Sosyal Politikalar Bakanlı̆̆ı'na özel vurgu yaptı. Başbakan, Çocuk Hakları Stratejisi'ne değinmedi. Millî Eğitim Bakanlığı'nın yeniden yapılandırılacağını açıkladı. Üstün yetenekliler konusuna ve kurulacak kuruma da atıfta bulunmadı. Başbakanımız, Süleyman Demirel ve Turgut Özal gibi sayıları çok seviyor. Siyasetin diline ekonomik büyüme ve kalkınma egemen. Nedense, Ankara sayıların diliyle konuşmayı çok seviyor.

\section{Nişantaş1, 24 Temmuz 2011}

24-25 Mayıs 2011 tarihlerinde düzenlenen Çocuk Yoksulluğu ile Mücadele Çalıştayı Sonuç Raporu yayımlandı. Türkiye'de 15 yaş altı çocuk grubunun \% 23'ü yoksul. Ülkemizin çocuk yoksulluğuyla ilgili köklü bir programı da yok henüz. Yoksulluk içinde büyüyen çocukların yetişkinliklerinde de yoksulluk içinde yaşama ihtimalleri çok yüksek. Mutlak yoksulluk yanında görece yoksulluk en fazla küçük yaşlardaki çocukları etkiliyor. Yoksul ortamlarda doğan çocukların sağlıklı büyüme ve sağlığını koruma yanında, büyüme ve gelişme haklarından yoksun kalmaları ise kaçınılmaz bir sonuçtur.

Çocuk yoksulluğuyla ilgili yardıma bağımlılık, suça itilme ihtimali, düşük eğitim, madde bağımlılığı, düşük gelir, işsizlik ve sağlık sorunları ise ilk sıradaki başlıklardır. Demografik bakımdan yoksulluk oranı en yüksek grup 0-18 yaş grubu çocuklardan oluşuyor. Hane halkı büyüklüğüne göre de çocuk yoksulluğu değişiyor. 1-2 kişilik hane halkı grubunda yoksulluk oranı \%11.5 iken, 3-4 kişilik hane halkı grubunda \%9.4, 5-6 kişilik hane halkı grubunda ise \%21.8. 7 kişiden fazla hane halkı grubunda bu oran \%38.5. Kırdaki yoksulluk şehirdekine göre daha geniş ve ağır. Yıllardır yazdık söyledik; aile ve çocuk odaklı sosyal programın hazırlanması ve uygulanması şart. Sağlık, barınma, eğitim, hizmetlere erişim, sosyal güvence hakları ve kültürel hizmetlerin yaygınlaştırılması programı ile çocuk yoksulluğunun önlenmesi ülke politikası durumuna getirilmedikçe yoksulluk ve çocuk yoksulluğu sarmalı derinleşmeyi sürdürecek...

\section{Nişantaşı, 24 Mayıs 2012}

Aile ve Sosyal Politikalar Bakanlığı Müsteşarı Kenan Bozgeyik Ankara'da SHÇEK'in eski binası ve Çocuk Sarayı Apartmanı'nda kurulacak çocuk müzesi için yardımcı olmamı istemiş ve bu konuda Özcan Kars'ı görevlendirmiş. Bekir Onur'un raporunu dün okudum. Gönderdiğim kısa raporun sonuç bölümünü günlügüume kaydediyorum: 
Müzeler, toplumların kültürel algılarını biçimlendiren kültür kurumlarıdır. Yeni dünyada müze anlayışının geldiği nokta, müzelerin eğitim yönünü öne çıkarmıştır. Artık müzeler, koleksiyoncu dükkânı değildir. Nesne sergilemeye yönelik müzecilik dönemi kapanmıştır. İnsana yönelik eğitim ve iletişim ağırlıklı bir müzeciliğe göre kurulacak müzenin amacı ve işlevi belirlenmelidir. Müze dünyası ile eğitim dünyasını içine alan bir yaklaşıma odaklanmak gerekir. Kurulacak müzeyi müze bilim ve eğitim psikolojisi temelinde öngördüğümüzde kurum müzesi mi bilim-sanat ağırlıklı bir müze mi kurmak gerektiği kararı da verilmiş olacaktır.

\section{Nişantaşı, 28 Ağustos 2012}

Bugünkü Taraf gazetesinde yer alan haber: Dünyanın en büyük üçüncü tüketici malları üreticisi Unilever Grubu Avrupa Şefi Lan Zijderveld, gelişmekte olan ülkelerdeki stratejilerle Avrupa'daki krize karşı mücadele ettiklerini ifade ederek, fakirlik Avrupa'ya geri dönüyor, demiş. Şımarık Batı'nın 'tarihin sonu tezi'ni yalanlayan bu habere sevinemedim. Çünkü doğacak Avrupalı çocuklar üzülecek...

\section{Tarabya, 8 Eylül 2012}

Dokuz 5 Yıllık Kalkınma Planı geride kaldı. Ekonomik büyüme ağırlıklı planlı kalkınma yaklaşımı miadını doldurduğu hâlde 2014-2018 yıllarını kapsayacak X. Plan hazırlıkları başlamış. Yarın, öğleden sonra Çocuk Özel İhtisas Komisyonu için Ankara'ya gideceğim.

Birkaç gündür bisikleti icad eden Kirkpatrick Macmillan'ın şu cümlesi zihnimde dolaşıyor: Bisikleti icat ettiğim kadar iyi kullanamadım, çünkü, bisiklete bindiğim ilk gün adam ezdim. Türkiye için Kalkınma Planları da tam bir memleket kazasıdır. On yıldır ülkeyi yönetenlerin hâlâ bunu fark edememiş olması kaygı vericidir. Anlamaları için de bir şey söylemeli miyiz? İnce ayarlı bir söz söylemek yeterli: Kuş gibi uçmak arzusuyla bisiklete binersiniz ama uçakla uçamazsınız, çünkü uçağa binersiniz.

\section{Tarabya, 6 Ekim 2012}

Hakan Yılmaz tarafından yapılan Türkiye'de Muhafazakarlı: Ailede, Cinsellik, Din Araştırması sonuçlandı. Araştırmada en dikkat çeken nokta, muhafazakâr tutumlardaki yumuşama eğiliminin ortaya çıkmış olması. Araştırmanın ilgi çekici sonuçlarından biri, muhafaza edilmesi gereken en önemli toplumsal kurum ve muhafaza edilmesi gereken en önemli siyasal değer konusunda değişim olmuş. Muhafaza edilmesi gereken en önemli toplumsal kurum aile oranı yüzde 54'e yükselirken, devlet yüzde 15,5'e gerilemiş. Muhafaza 
edilmesi gereken en önemli siyasal değer 6 yıl önce "eşitlik" iken, artık özgürlük.

Açık Toplum Vakfi ve Boğaziçi Üniversitesi tarafından yürütülen Türkiye'de Orta Sınıfi Tanımlamak Araştırması da sonuçlanmış. Araştırmaya göre kendini orta sınıf olarak görenler azalmış, kendini fakir bulanların sayısı artmış. Kazandığımız para, bize yetmiyor diyenlerin oranı 6 puan artışla yüzde 47'ye çıkmış. Dindarlık seviyesi 6 yıl içinde kayda değer bir değişim geçirmemiş. Ramazanda oruç tutanların oranı yüzde 60'tan yüzde 53'e gerilemiş.

Yılmaz Esmer'in hazırladığı Türkiye Değerler Araştırması 2012 de sonuçlanmış. 1990'dan bu yana iki yılda bir sürdürülen araştırmanın öne çıkan sonuçları şöyle: Toplumda güven duygusu zayıflıyor; dindarlıkta artış var, muhafazakârlıkta yükseliş yok; otoriter eğilimler güçlü, demokratik değerler zayıf...

Türkiye'de aile, çocuk ve gençlik araştırmaları için ölçek geliştirilmesine ihtiyaç var. Ailenin, çocuğun, gencin iyilik hali endeksi sistemi kurulmadan ampirik çalışmaları ihtiyatlı değerlendiriyorum.

\section{Tarabya, 8 Aralık 2012}

WIN/Gallup International Global Açlık Algısı Araştırması sonuçları her anlamda uykuları kaçıracak cinsten: Oluşturulan açlık duygusu endeksine göre dünya nüfusunun yüzde 3'ü sürekli, yüzde 9'u zaman zaman açlık çekiyor. Zaman zaman ya da sürekli açlık hissi duyan yüzde 12 oranı dünya nüfusunun 840 milyonu demek. Kriz bölgelerine gelince: Sudan halkının yüzde 80'i, İsrail ablukası altındaki Filistin'de ise halkın yüzde 52'si yeterli gıdaya ulaşamadığı için açlık içinde yaşıyor.

Açlık Algısı Araştırması Türkiye Sonuçları'nı Türkiye'nin iyi yönetildiği iddiasını sürdüren politikacılara ithaf ederek buraya kaydediyorum: Türkiye nüfusunun yüzde 4.6'sı sık sık, yüzde 11.6'sı da zaman zaman yeterli gıda bulamıyor. Türkiye'de açlık çekenlerin oranı toplam yüzde 16.2. Bu oran, yüzde 12 olan dünya ortalamasının üzerinde. Sürekli veya ara sıra yeterli gıda bulamayanların oranı, çalışanlar arasında yüzde 12 iken, çalışmayanlar arasında yüzde 19.3.

Türkiye'de iki haftadır Muhteşem Yüzyıl dizisi tartışılıyor. Bakalım yoksullar ne zaman gündeme gelecek!

\section{Nişantaşı, 30 Ocak 2013}

TÜİK'in son araştırmasına göre nüfus artış hızı 1.35'ten 1.2'ye, 0-14 yaş grubunun toplam nüfusa oranı ise 25 'in altına düşmüş. Başbakan Recep 
Tayyip Erdoğan'ın 'üç çocuk' çağrısına rağmen nüfus artış hızı azalınca, Hükümet, çocuk sayısını teşvik etmek amacıyla çalışmalara başlamış. Nüfus artışı ve azalmasının birçok bileşeni var. Sayılar üzerinden yapılacak değerlendirmelerle sonuç alınacağını varsaymak yerine, nüfus azalmasının nedenlerini anlamaya yönelmeyi tercih etmeliyiz. Büyük nüfus söylemi yerine çocuk sorunlarının çözümünü birinci öncelik durumuna getirmek daha gerçekçi değil mi?

TÜİK'in çocuklara ilişkin istatistikleri 2006 Aile Yapısı Araştırması veri tabanına dayanıyor. Bu ise çocuk gerçeğinin üzerini örtüyor. Veri tabanının güncellenmesi gerekir. Çocuğun İyi Olma Hali Endeksi sisteminin kurulması halinde bu konudaki doğru bilgi ihtiyacı karşılanmış olur.

\section{Tarabya, 8 Mart 2013}

Memnuniyetsizlik Araştırması'na göre, mutlu olanların sayısı önceki seneye göre yüzde 1 azalarak yüzde 61'e inmiş. Manolya ağacım, bu sonucu nasıl yorumlamalı?

\section{Tarabya, 16 Mart 2013}

Çin'de 1971 yılından beri başlayan 'tek çocuk' politikası sonucunda 336 milyon kürtaj yapılmış; 196 milyon kadın ve erkek kısırlaştırılmış. Birçok aile, erkek çocuk tercih ettiği için daha çok kız çocuklar aldırılmış. 2033'e kadar 60 yaş ve üzeri nüfusun 400 milyonu aşacağı tahmin ediliyor... Çin'in bir gün çökeceğine dair bir çok neden sıralanabilir. İlk neden ise cenin hakları ve bebek katliamıdır. Dünya ise Çin'e karşı suskun; insanlığın masumiyeti böyle mi savunulacaktı!

Katolik âleminin yeni ruhani lideri Papa Francesco, 'yoksullar için ve yoksullara çalışan bir kilise' vaat etmiş. Yeni Papa, Vatikan'ın küplerini yoksullara dağıtmadıkça bu sözün hiçbir anlamı yok!

\section{Nişantaşı, 3 Nisan 2013}

TÜİK, 6-17 yaş grubunda 15 milyon 247 bin çocuk olduğunu açıkladı. 6-14 yaş grubunda 292 bin, 15-17 yaş grubunda ise 601 bin çocuk işçi çalışıyor. 6-14 yaş grubunda çocukların yüzde 97.2'si, 15-17 yaş grubunda ise yüzde 74.7'si okula devam ediyor. Çalışan çocukların yüzde 68.8'ni erkek, yüzde 31.2'sini ise kız çocuklar oluşturuyor. Türkiye, dünyadaki büyük ekonomiye sahip 20 ülke arasında olmasına rağmen; çocuk yoksulluğu Türkiye'de 10 yıl öncesinden farklı değil. Hükümet, 13 milyon bireye 'sosyal yardım' yapmış. İhtiyaç temelli anlayışı yaygınlaştırmış. Ancak, henüz hak ve sorumluluk 
temelli bir anlayışa hazır olmadığı gibi sosyal koruma hukuku geliştirmeye de hazır değil.

\section{Tarabya, 28 Nisan 2013}

Ekonomik büyüme ve kalkınma ile çocuğa yönelik harcamalar arasındaki ilişki çocuk lehine bir denge içinde değil. Yıllardır söyledim, yazdım. Hafta içinde Kalkınma Bakanı Cevdet Yılmaz, iktidarlarının on birinci yılında nihayet bu yönde bir açıklama yapmış.

İstanbul Bilgi Üniversitesi'nin hazırladığı STK'lar İçin Çocuğa Yönelik Harcamaları İzleme Kılavuzu'na göre, çocuğa yönelik kamu harcamalarındaki artış Gayri Safi Yurt İçi Hasıla artış hızının gerisinde kalmış. Bunun anlamı çok açık; ekonomideki büyüme çocuğa yeterince yansıtılmıyor. Araştırmada en temel sorunlar ve kaynak aktarılması gereken başlıklar arasında çocuk yoksulluğu ile mücadele geliyor.

OECD verilerine göre Türkiye'de dört çocuktan biri hâlâ yoksul. Bahçeşehir Üniversitesi'nin, Türkiye'de Her Üç Çocuktan Biri Yoksul başlıklı araştırmasına göre, Türkiye'de 4.6 milyon çocuk beslenme, ısınma ve giyim gibi temel ihtiyaçlarını karşılayamıyor.

TÜİK'in, Gelir ve Yaşam Koşulları Anketi verilerine göre ise maddi yoksunluk çeken çocukların arasında 2006 yılından 2010 yılına kadar bir iyileşme kaydedilmiş... Yardım dağıtmakla çocuk yoksulluğunun kökten çözümü erteleniyor. Devlet'in verdiği yetmiyor. Bu sorun öncelikle sistem sorunudur ve henüz kökten çözüme gitmek için de çok erken. İktidarı yoksullarla bölüşmek kolay mı!

\section{Nişantaşı, 29 Nisan 2013}

Kalkınma Bakanı Cevdet Yılmaz'a bugün gönderdiğimiz mektupla, Çocuğun Iyi Olma Hali Endeks Sistemi'nin kurulmasını önerdik. ${ }^{2}$ Çocuğun İyi Olma Hali Endeksi, çocuğu bir bütün olarak ve şimdiki ihtiyaçlarını dikkate alarak 'iyi olma'sının göstergelerini belirlemek amacıyla kurulmalı. Türkiye'nin hane halkı anket bilgilerinden göstergelere dayalı bir veri tabanı anlayışına geçilebilmesi için de bu sisteme ihtiyaç var. 1. Çocuk Hakları Stratejisi ve Uygulama Planı'nda kurulması öngörülen bu sistem için dünya modellerinin incelenmesi gerekir. 
İhtiyaç temelli anlayıştan hak ve sorumluluk temelli anlayışa geçiş için çocuk göstergelerinin tespit edilmesi çocuğu ilgilendiren sorunların çözüm için de önemli bir adım olacak. Uygulamanın ölçülmesi, değerlendirilmesi, izlenmesi ve denetlenmesi bir sistem ihtiyacını zorunlu kılmaktadır. Çocuğun İyi Olma Hali, maddi durum, sağlık, eğitim, ev ve çevre koşulları, güç koşullar ve güvenlik, katılım, sosyal ilişkiler, öznel iyi olma hali olmak üzere 8 başlık altında oluşturulacak göstergelerle yeni doğan kuşakların yaşama, gelişme ve korunma haklarıyla etki analizlerini de yapabilecek duruma geleceğiz. Bakalım Çocuk Vakfı'nın bu hayalinin gerçekleşeceğini görebilecek miyim?

\section{Nişantaşı, 13 Mayıs 2013}

Hükümet, bir yandan kadınların iş gücüne daha çok katılmalarını, bir yandan da ailelerin daha çok çocuk sahibi olmalarını sağlayacak düzenlemeler üzerinde çalışıyormuş. Başbakan Yardımcısı Ali Babacan, birkaç hafta içinde bu çalışmayı Başbakanın açıklayacağını bildirmiş. Başbakanın 'büyük nüfus' meselesine bu kadar ağırlık vermesi doğurganlığın azalma eğilimine dayanıyor. Mevcut çocuk nüfusunun aldığı hizmetlerin niteliğini artırmak mı çocuk sayısının artışı için teşvik mi? Gönlüm aile ve çocuk odaklı hizmetlerin niteliğinin artmasından yana. Çünkü bunun sonrasında doğurganlık normal seyrine kavuşabilir.

\section{Tarabya, 29 Haziran 2013}

Hava kapalı, esintili ve serin. Haziranda bundan iyisi can sağlı̆̆ı... Radikal gazetesindeki "Aile Dostu Kampanya” ise can sıkıcı. Aile ve Sosyal Politikalar Bakanı Fatma Şahin, kampanyanın 'temel felsefesini' şöyle açıklamış: "Innsana yatırım yapmak için ilk müessese ailedir ve aile çözümün merkezidir.” Aileyi özendirmek ve güçlendirmek için başlatılan bu kampanya, "Aile Dostu" logolu ürünlere odaklı. İletişimden spor salonuna, konuttan kültürel faaliyetlere kadar yüzde 10 indirim. Aile ve Sosyal Politikalar Bakanlığı, Hükümetin birinci etkinlik Bakanlığı gibi. Bakanlığın kurulmasını önerirken 81 il 957 ilçede icracı bir Bakanlık öngörmüştük. 2 yılda gelinen bu aşama can sıkıcı, evet çok can sıkıcı...

\section{Tarabya, 10 Ağustos 2013}

181

Çocuk ve Medeniyet 2021/1
2 Temmuz 2013 tarihinde kabul edilen X. Beş Yıllık Kalkınma Planı 20142018 belgesi beş haftadır masamın üstünde. Planın girişinde iddialı sayılabilecek dünya analizine karşılık, Türkiye'nin mevcut durumu bu analizin bileşenleri ile ilişkilendirilmemiş. Yapılanlar anlatılmış, 
geliştirilmesi gereken yönlerimize yönelik stratejiler geliştirilmemiş. Son beş yıllık planı temenniler kataloğu olarak da adlandırabiliriz. Ne temel öncelikler ne de stratejik amaçlara yer verilmiş. Üçüncü bölümdeki öncelikli programlar da stratejik ifadelere dayanmıyor. Öncelikli programlar kısmı ise önerilen faaliyetler şeklinde okunabilir. Plan'ın yapısında amaçlar/ hedefler/ politikalar açık ve seçik şekilde yer almadığı için kamu kurum ve kuruluşlarının stratejik planlarına nasıl yansıyacağı belirsiz. Plan okundukça, Türkiye'nin son yıllardaki iyi yönlerine odaklanmış icraatın içinden duygusu veriyor.

Necmettin Oktay'ın tespitine göre, Plan, hiyerarşi açısından, stratejik amaçlar, stratejik amaçlarla bağlantılı hedefler ve bu hedeflere destek verecek politikalar şeklinde yapılandırılmış olsaydı, (giriş kısmındaki 7. maddede ifade edildiği gibi) kamu kurum ve kuruluşları için yönlendirici, daha sistematik ve kavramsal olarak da daha anlamlı ve anlaşılabilir olması sağlanabilirdi. Necmettin Hoca, "Kalkınma Planı stratejik plan değildir midir?" sorusu için şu değerlendirmeyi yapıyor: Bu politika belgesinde amaçlar/hedefler/ve politika kavramları yer aldığına göre bu kavramların tanımına uygun ifade edilmesi ve kullanılması gerekirdi. Bu nokta şu bakımdan önemli: Hazırlanan planların uygulanması ve izlenmesinde yaşanan sorunlar aşılamıyor.

X. Beş Yıllık Kalkınma Planı'nda 'kritik reform alanları' için Öncelikli Dönüşüm Programları arasında ne eğitim ne de kültür başlığı var. Eğitimle ilişkili iki başlıkta ise temel ve mesleki becerileri geliştirme ile nitelikli insan gücü için çekim merkezi programı notu var. Plan'da, ailenin ve dinamik nüfus yapısının korunması programına karşılık, çocuğa yönelik öncelikli bir yaklaşım ve program da yok.

Türkiye'nin son Kalkınma Planı, öncekiler gibi ‘ekonomik büyüme ve kalkınmaya odaklı' bir plan içeriğindedir. Ne zihniyet ne de yapısal değişimleri hedeflemektedir. Çocuk bağlamında Çocuk ve Gençlik başlığı altındaki analize dayalı amaç ve hedefler/politikalar (s. 44-45) dikkate alındığında şu tespitte bulunabiliriz: Çocuk sorunları mevcut anlayışla çözülebilir. Bu ise geçmişte ve bugün ülkeyi yönetenlerin çocuk meselesini kavrayıştan uzak olduklarını ortaya koyan temel yanılgıdır...

\section{Tarabya, 11 Ağustos 2013}

\section{2}

Çocuk ve Medeniyet 2021/1
Kimsesiz Çocuklar, Osman K. Akol'un 1950 yılında Örnek Matbaası'nda basılmış kitabının adı. Kitabın kapağında sırtını ağaca dayamış çocuk deseni. Kitap 1882'de Darülâceze'nin kurulmasına öncülük eden Dâhiliye Nazırı Halil Rifat Paşa'dan, Darüleytamların kurucusu İsmail Mahir Efendi’ye, 
Çocuk Esirgeme Kurumu'ndan Hasip Akıncı'nın İzmir'de kimsesiz ve sokakta kalmış çocuklar için kurduğu Sepetçilik ve Çiçekçilik Mektebi'ne kadar özet bir çocukluk tarihi. CHP'nin 1945 Çocuk Raporu'na rağmen de çocuk yoksulluğu ve korunmaya muhtaç çocuklar Devletin ciddi işleri arasına dâhil edilmemiş. Osman K. , Kimsesiz Çocuklar kitabında aile, çocuk, engelliler ve Çocuk Hakları konusunda Çocuk Esirgeme Kurumu'nu yönetmiş Dr. Fuat Umay döneminin yıllık bütçelerinin dökümünü yaparak eleştiriyor. Bu konuda, Fuat Umay'ı bu kadar sert eleştiren başka bir yazı okuduğumu hatırlamıyorum. Öğretmen kökenli Osman K.'nın kimselikimsesiz ayrımı yapmadan meseleyi 'çocuk davası' teması etrafında izah ettiği yıldan bu yana 60 yıl geçmiş. Bugün de esas olan, kurumlardan önce, 'çocuk davası' anlayışına sahip idealist insan eksikliğidir.

\section{Tarabya, 18 Ağustos 2013}

Türkiye yoksulluğu ölçemeyen bir ülke durumunda. Nasıl ölçülsün ki! Yoksulluk ölçülebilir mi!

Yoksulluğu ölçmek için Ulusal Yoksulluk Sınırı (UYS) ve Bölgesel Yoksulluk Sınırı (BYS) ölçütleri kullanıldığında, bölgeler için yoksul sayısı farklı çıkabiliyor. Türkiye'de bölgeler arası gelir farklarının yüksek olması nedeniyle, İstanbul'da yoksul sayısı çok düşük çıkarken, Güneydoğu Anadolu'da abartılı şekilde çok yüksek çıkabiliyor. Seyfettin Gürsel 3. bir yol önermiş: Temel Maddi Yoksunluk (TMY). TÜİK verilerine bu ölçüte göre bakıldığında ise yoksulluk azalıyormuş. İktidarı yoksullarla paylaşamayanlar için 'bedava' bir mazeret daha...

\section{Nişantaşı, 20 Ağustos 2013}

Kayıp çocukların yüzde 65'i kız, yüzde 35'i erkek. Aile ve Sosyal Politikalar Bakanlığı'nın yurtlarında 'açık kapı' uygulaması nedeniyle kayıp çocukların yüzde 33'ü kurumlardan, yüzde 67'si ailelerinden kaçıyor. Yıllarca İdarî ve Adlî Koruma Sistemi'nin kurulması önerildiği halde ne duyan oldu ne de anlayan!

\section{Tarabya, 8 Eylül 2013}

TÜİK'in son yıllarda yaptığı araştırmalardan ülkeyi yönetenler yararlanıyor mu? Ya da ne kadar yararlanıyor? Çocuk işçiler konusu bütün dünyanın gerçek çocuk sorunlarından biri. Dünyada 215 milyon 'çocuk işçi' tarım ve ağır işlerde çalışırken, çözüm üretmesi gereken hükümetler sorunları yamamaktan öte bir şey yapmıyor. Asıl mesele yoksullarla iktidarı paylaşmak. Dünyada buna cesaret eden iktidar var mı? 
TÜİK'in 2012 yıl sonu verilerine göre ev işlerinde faaliyette bulunan 7,5 milyon çocuğumuz var. 893 bin 'çocuk işçi' çalışıyor. 614 bini erkek, 279 bini kız. Kırsal alanlarda 493 bin çocuğun 368 bini tarım sektöründe. TÜİK verilerine göre kaygı verici olan diğer bir sonuç ise 'çocuk işçi' sayısında artış olması. Son yıllarda Hükümetin başlattığı Şartlı Eğitim Yardımı ile 2,5 milyar dağıtılmış. İhtiyaç Temelli anlayışa göre çocuk yoksulluğunun önlenemeyeceğinin Hükümetler farkında olsa da, yüksek maliyet nedeniyle hiçbiri bu köklü çözüme cesaret edemiyor. Aile bireylerinin sosyal güvenceye kavuşturulması, işsizliğin önlenmesi, sağlık yardımları kapsamının genişletilmesi yanında, yoksulluğun ve özellikle çocuk yoksulluğunun önlenmesi için Devlet'in Hak ve Sorumluluk Temelli Anlayışı Sosyal Koruma Hukuku'na dayandırması, buna dayalı bir dönüşüm öngörmesi ve bu politikasını buna göre yapılandırması gerekiyor. Buna cesaret edebilecek iktidarlar Türkiye'de sosyal adaleti sağlayabilir ve sosyal devleti yeniden inşa edebilirler...

\section{Nişantaşı, 15 Kasım 2013}

Az önce I. Türkiye Çocuk ve Medya Kongresi'nin veda fotoğrafının içinde yer aldım. Bir çocuk ödevinin sonuçlanmış olmasından dolayı durgun bir göl gibiyim. Teşekkür konuşmamın son bölümünde duygulu anlar yaşadım. Hüngür hüngür ağlamamak için kesik kesik konuşmuşum. Buna rağmen, küçük bir hayalimi daha açıkladım:

Türkiye'nin yoksul köylerinden birinde Çocuk Yoksulluğu Kongresi düzenleyeceğiz. Yalnızca ülkemizin değil 7 kıtanın yoksul çocukları için. Her kıtadan temsilci çocuklar. Her kıta için bir çadır. Çadırların renkleri farklı. Köyün sınırlarından içeri hiçbir marka alınmayacak. Yoksulların yediği kadar yemek ikram edilecek. Kongreyi dünün, bugünün ve geleceğin politikacılarına ithaf edeceğiz. Zenginlerden bağış-yardım kabul edilmeyecek... Kongre öncesi, sırası ve bir hafta sonrasına kadar internet sitelerinden birkaç dilde yayın yapılacak. Çocuk yoksulluğu temaları günlük programlar içinde sunulacak. Kongre sonunda Dünya Çocuk Yoksulluğu Bildirgesi açıklanacak...

Birazdan Çocuk Vakfi'ndan evlerimize gideceğiz. 435 gün sonunda hiç yorulmamış gibiyim. Allah'ım hangi melek kaldırdı üzerimden Kafdağı kadar ağırlığı?

\section{Tarabya, 17 Kasım 2013}

Çocuk ve Medeniyet 2021/1
7 kıtayı temsilen 7 metre yüksekliğinde ve küreden oluşan bir kumbara. Kumbara şeffaf ve boş. Günlük harçlıklarımızla Çocuk Yoksulluğu Kongresi'ni düzenleyeceğiz. 


\section{Nişantaşı, 24 Kasım 2013}

Az önce, ilkokul dördüncü sınıf öğretmenim Bedri Bahar'ı aradım. Bedri Bey öğretmenim 71 yaşında. Süphan Dağı eteklerinde hiç yeni elbise giymemiş çocuklara da öğretmenlik yapmış. Okul, açık havada. Çimenler kilim. Katır sırtında gidip gelmiş her gün. 'Hakikatin ta kendisiydi yaşadıklarımız' derken titrek sesinde bu görevi yapmış olmanın bahtiyarlığını hissettim... Aradan tam 50 yıl geçmiş: Azalsa da yoksul çocuk hikâyeleri o kadar çok ki! O kadar uzağa gitmeye de gerek yok. Tarabya'nın bile aç uyuyan çocukları ağlasa dünya uyuyamaz.

\section{Nişantaşı, 16 Aralık 2013}

OECD’nin Yaşam Kalitesi Endeksi'ne göre Türkiye en son sırada. Türkiye'de çalışan kesim yılda 101 saat daha fazla çalışıyor. Türkiye, dünyanın 17. büyük ekonomisine sahip. Her ay 100 kişi iş cinayetlerinde ölüyor. İş güvenliği tehlikeli boyutlarda. Tam anlamıyla emek sömürüsü. İşçilerin yalnızca yüzde 5'i sendikalı. 34 OECD ülkesinin yıllık kullanılabilir hane halkı geliri ortalama 23 bin dolar. Türkiye'nin ortalaması 14 bin dolar düzeyinde. "Ekonomik büyüme” masalını dillerinden düşürmeyenlere duyurulur...

\section{Tarabya, 8 Mart 2014}

Acı bir çocuk haberi daha: Haberin kaynağı, Aile ve Sosyal Politikalar Bakanlığı. Türkiye'de 2002-2013 yılları arasında 504 bin 957 çocuk erken yaşta evlendirilmiş. Daha acı bir çocuk haberi daha: Son 3 yılda 17 bin kız çocuğu kayıp. Son yıllarda hiçbir çocuk sorunu çözülemedi. Ne adlî ne de idarî koruma sistemi kurulabildi. Aile Bakanlı̆̆ı'nın kurulması için çeyrek yüzyıl boyunca çırpındık. Önerimiz üzerine Aile ve Sosyal Politikalar Bakanlığı kuruldu; fakat bir türlü etkinlik düzenlemekten icracı bir aile ve çocuk Bakanlığına sıra gelmedi.

\section{Tarabya, 17 Nisan 2014}

Türkiye'de Kadınlarm Sosyal, Kültürel, Siyasal ve Ekonomik Durumu Araştırması'na göre kadınların yüzde 70'i 21 yaşından önce evleniyor. ${ }^{3}$ Çocukluk çağı evliliklerde en yüksek oran yüzde 20,6 ile Doğu Anadolu'da.

3 Bu araştırmada olduğu gibi Türkiye'de erken yaşta evlendirilen çocuklar için "çocuk gelin" adlandırması kullanılıyor. Çocukluk çağı evlilikleri veya erken yaşta evlendirilen çocuklar adlandırılmasının kullanılmasını öneriyoruz. 
Diğer iki bölgemiz ise yüzde 17,3 ile Orta Anadolu, yüzde 15,5 ile Kuzeydoğu Anadolu. Daha trajik olanı ise 16 yaşından küçük evlilik yapanların oranı yüzde 10. 18 yaşından küçük olanların oranı ise yüzde 34 . Bu araştırma, Doğu ve Güneydoğu'da erken yaş evliliklerinin çok olduğu algısının yanlış olduğunu ortaya koymuş oldu. 10-12 yaş arası evlilikler ise daha çok Kuzeydoğu Anadolu; 12-13 yaş evlilikleri ise Orta Anadolu ve Doğu Anadolu bölgelerinde gerçekleşiyor. Ne yazık ki çocuk yaşta evlilikler konusunda hâlâ bir sosyokültürel programa sahip değiliz.

\section{Tarabya, 23 Nisan 2014}

Bahçeşehir Üniversitesi, bugün, Üç Çocuktan İkisi Şiddetli Maddi Yoksunluk Çekiyor, başlıklı araştırma notunu yayımlamış. TÜIK'in, Gelir ve Yaşam Koşulları Anketi ( GYKA ) 2011 yılı verileri kullanılarak hesaplanan oranlara göre, 2011 yılında Türkiye'de yaklaşık her üç çocuktan ikisi Avrupa standartlarına göre şiddetli maddi yoksunluk içinde yaşıyor. AB tanımına göre, şiddetli maddi yoksunluk, bireylerin hayatlarına düzgün bir şekilde devam edebilmeleri için gerekli olan çeşitli ihtiyaçların zorunluluktan yerine getirilememesi olarak tanımlanıyor. Daha da ilginç bir sonuç ise, Türkiye, çocuklar arasında şiddetli maddi yoksunluk açısından hem Güney Avrupa ülkelerinin hem de daha düşük gelişmişlik düzeyine sahip Macaristan, Romanya gibi ülkelerin oldukça gerisinde.

Türkiye'de çocukların yüzde 67,7'si iki günde bir protein tüketemiyor, yüzde 39,9'u yeterince ısınmayan evlerde yaşıyor ve yüzde 40'ı eskiyen kıyafetleri yerine yenilerini alamıyor. Bu üç temel ihtiyacın hiçbirini gideremeyen çocukların oranı ise yüzde 24,8 .

BETAM, yoksulluğun gidişatını takip etmek ve öncelikle en zor durumlardakilere ulaşabilecek politikalar geliştirebilmek için yeni bir tanım önermiş: Temel maddi yoksunluk tanımına göre üç temel ihtiyaç olan; evi yeterince ısıtma, iki günde bir et, tavuk, balı gibi protein tüketebilme ve eskiyen kıyafetlerini yenileriyle değiştirebilme ihtiyaçlarının hiçbirini karşılayamayan bireyler temel maddi yoksunluk içerisinde kabul edilmektedir.

BETAM'ın araştırma notunda, Türkiye'de çocuk yoksulluğunun şiddetli ve inatçı olduğu görüşüne de yer verilmiş. Bu gidişle Hükümetin yoksulluğu önleyecek etkin politikalar geliştireceği çok zayıf bir ihtimal.

Ek bir not: Ünlü fizikçi Stephen Hawking, yapay zekâ teknolojilerinin kontrolsüz gelişimi ile ilgili uyarıda bulunmuş: Yapay zekâ teknolojileri hastalıkları, savaşları ve fakirliği sona erdirebilir. Hawking'in kaygısı ise insanların daha fazla keşif yapıp, tehlikeli silahlar geliştirilmesinin ise 
daha büyük yıkım getirebileceği yönünde. Anlaşılan, hastalık, yoksulluk ve savaşlar için insanlığın çaresizlik sarmalı çözülemeyecek.

\section{Tarabya, 15 Temmuz 2014}

Diyanet İşleri Başkanlığı'nın yaptığı araştırmaya göre Türkiye'nin yüzde 99.2'si Müslüman. Dindarlığın hayata nasıl yansıdığı da araştırılmış. Müslümanların yüzde 71.9 zekât veriyor; yüzde 41.9'u Kur'an okuyor; eş seçiminde öncelik yüzde 68.4 ile dindarlıkta. Çocuklar dini bilgileri en çok 6-10 yaş grubundayken öğreniyor. Çocuklarını "İslami hassasiyete göre" yetiştirmek isteyenlerin oranı ise yüzde 87.1... Din ve değerlere yönelik nicel araştırmalara güvenim yok. Bu sonuçlar ile içinde yaşadığım toplumun ne kadar örtüştüğü hakkında kaygılıyım. Nasıl bir Müslümanlık yaşandığı ortada. Yüzde 71.9'u zekât verdiği hâlde Türkiye'de yoksulluğun hâlleri niçin hep aynı?

\section{Nişantaş1, 27 Nisan 2015}

Kalkınma Bakanı Cevdet Yılmaz, "güçlü sosyal devlet" vizyonu ile yoksulluğun ortadan kaldırıldığını ve gelir dağılımındaki dengesizliğin “asgariye” ineceğini açıklamış (!) İki cümlesi de şöyle: “OECD verilerine göre, Türkiye'de yıllık ortalama gelir artışı düşük gelirlilerde yüksek gelir grubundakilere göre daha fazla. Güçlü sosyal politikalarla refahın adil dağılımı sağlandı." Bu açıklamalardan, zenginle-fakir arasındaki uçurumun azaldığı anlatılmak isteniyor... Gelir dağılımındaki eşitsizliği ölçen Gini Katsayısı 2002'de 0.44'müş, bu yıl 0.38'e düşmüş. OECD verilerine göre yoksulluk oranları 2011'de yüzde 19'muş. TÜİK verilerine göre bu oran 2013'te 14.9'a inmiş.

Sosyal yardımlarla yoksulluk kökten çözülmez, ertelenir. Son yıllarda sosyal yardımlara ağırlık verildiği hâlde niçin yoksulluğun önlenmesi amacıyla köklü atılım yapılamadı? İktidar, yoksulların yardım payını artırmakla yetindi, yoksulluğun önlenmesine yönelik bileşenlerin durumunu iyileştirmeye, istihdama, sosyal koruma hukukunu geliştirmeye öncelik veremedi. Sonuç olarak, iktidarını yoksullarla bölüşemedi.

\section{Nişantaşı, 2 Ekim 2018}

Son günlerde metroda okuduğum kitabın adı Refah Devletinin Krizi. Pierre Rosanvallon'un ilk cümlesi "Refah devleti hasta." Devletin hastalığının teşhisi, sağlık harcamaları ile sosyal harcamaların ve sosyal harcamaların gelirlerden çok daha hızlı bir biçimde artıyor olması yönünde. Rosanvallon sanayileşmiş ülkelerin yirmi yıldan beri yaşamakta olduğu finansman 
açı̆̆ının nedenini de bu teşhise dayandırıyor. Pierre Rosanvallon'a göre, 20. Yüzyıl refah devleti "klasik" koruyucu devletin derinleştirilmiş ve genişletilmiş hâlidir; koruyucu devlet modern devleti özel bir siyasal biçim olarak tanımlar. Refah devletinin modern sigortacılık tekniklerinin evrilmesi sonucu yapılandırıldığı ise ortak kabullerden biridir. Batı'da refah devletinin düşünce temelleri 1970'lerden bu yana tartışılıyor. Refah devletinin demokratik ve eşitlikçi kültüre dayalı olması özgürlüklerin genişlemesini sağlarken özellikle muhafazakâr politikacılar tarafından güvenlik talebi ileri sürülmektedir. Refah toplumunun krizinin ekonomik boyutundan ziyade ahlaki bir krizin eşiğinde olduğuna yönelik kaygılar karşısında Pierre Rosanvallon'ın iki sorusu dikkat çekici: Demokratik aydınlık çağına girmeyi bilecek miyiz? Toplum kendine hangi dayanışma normlarını vermektedir?

Devlet-fert tartışmalarında ortak kabullerden biri de "refah devleti toplumsal olanı sadeleştirerek ferdi özgürleştirdiği" yönündedir. Devletin sorunları çözen bir aygıt olduğunu kabul edenlerle asıl sorunun devletin kendisinde olduğunu ileri sürenler arasında uzlaşma nasıl sağlanabilir? John Rawls'in 1970'li yıllarda geliştirdiği “düzenli bir toplum” için yaptığı öneriyi not edeceğim: "Herkesin, diğerlerinin de kendisiyle aynı adalet ilkelerini kabul ettiğini bildiği ve kabul ettiği; temel toplumsal kurumların bu ilkeler açısından genel olarak tatmin edici olduğu ve tatmin edici olarak kabul edildiği toplumdur." (s.77) Günümüzde ise refah devleti hakkındaki güncel tartışma, devletleştirme/özelleştirme alternatifine sıkışmış durumdadır... bir yanda "sosyal devletçi" senaryo, öte yandaysa "liberal" senaryo." Yirminci yüzyılın başından bu yana "toplumsal ilerleme talebinin" tek hedefi refah devletiydi. "Refah devleti laik devletin son sözüdür: Koruyucu devletin kendini dinsel olandan bağımsız kılarak egemenliğini ilan edişinin ardından, refah devleti dinsel olanı kendine dâhil ederek son izleri de siler. Yardımseverliğin ve korumacılığın belirsizliğinin yerini devletin düzeni alır.” (s.24-25).

Batı'daki refah devleti tartışmalarından Türkiye'nin payına ne düşer? Bu soruya bir soru ile cevap vermek daha gerçekçi olmamızı sağlayabilir: Türkiye'de devleti beka ve güvenlik meselesi dışında tartışan düşünce hareketi kaldı mı?

\section{Nişantaşı, 22 Kasım 2018}

Çocuk yoksulluğu üzerine doktora tezi hazırlayan Ercem Erkul ile dört saatten fazla bir süre konuşunca yorulmuşum. Yoksulluğun hâllerini hikâyeleriyle yaşıyorum. Yoksullara yönelik çok az iyilik ödevi yapabildim. 
Yıllardır düzenlemeyi düşündügüumüz Türkiye Çocuk Yoksulluğu Kongresi’ni de düzenleyemedik. Kongreyi düzenleyemeyince ne ülke ölçekli politikaya sıra geldi ne de Strateji ve Uygulama Belgesi’nin hazırlanmasına.

Yoksulluk ve çocuk yoksulluğu için mahalle merkezli modeller geliştirilmesini önereli de yıllar oldu. Bu modelin bölgelere göre işlevi farklı olacağı için uygulanabilir olduğunu düşünüyorum. Ne yazık ki iktidar partisi ayni ve nakdî yardımla sınırlı bir anlayışı sürdürmekten başka bir yolu denemeye yanaşmıyor. Tarım ve hayvancılığın çökertildiği bir ülkede işsizlik ve yoksulluk ilişkisi de kurabilmiş değil. İşsizlik yüzde 11.2, gençlerde işsizlik oranı yüzde 25. Kaç yıldır ısrarla önerdiğimiz hâlde Çocuğun İyi Olma Hâli Endeksi Sistemi'nin niçin kurulamadığı yoksulluğu konuştukça daha iyi anlaşılıyor. Ercem Erkul'un tezinde önereceği modeli merakla bekleyeceğim.

\section{Han Çayırı Yolu Sokağı, 18 Mayıs 2020}

Covid 19 salgını görünürde olan ve olmayan birçok insanlık durumunu açığa çıkardı: En önemli açık, modern uygarlığın insan, ahlak ve adalet açığı oldu. Ne yazık ki insanoğlu kardeş olmayı bilemedi. Ahlak ve adalet açığının değerler yanında dünya nimetlerinin paylaşılmasından ekonomik sisteme kadar birçok görünen ve görünmeyen yüzü vardır. Tarih boyunca insanlık, bencilliği ve mala-mülke tapıcılığı yüzünden nüfusun zayıf gruplarını en alta iterek bugünlere ulaştı. Salgınlar, afetler ve sistemlerin ekonomik krizleri hep bu en alttakileri daha olumsuz şartlarda yaşamaya mahkûm etti. Yoksulluğu çaresizlik sarmalına dönüştüren kötülüğün burgacına karşı da direnemedi insanlık.

Ve Covid 19 öncesi dünyada yoksulluk sınırının altındaki 3 milyar insanı devraldı dijital yeni dünya. Ne kadim insanlık değerleri ve dini değerler, ne seküler paradigma ve evrensel değerler, ne insan hakları söylemi, ne ülkelerin yoksulluğu önleme yaklaşımları, ne egemen sistemin sözde stratejileriyle yoksulluk dünyanın hiçbir yerinde önlenebilmiştir. Yoksulluk ve çocuk yoksulluğuyla ilgili sorularımız ve çözüm önerilerimizi geçersiz duruma getiren bu küresel salgın en alttakileri daha alta itecek. Çünkü salgının en olumsuz etkileri bütün dünyada ekonomik alanda hissedilecek. Çöken egemen dünya ekonomik düzeni kendini yeniden yapılandırırken yeni örgütlenme tarzları da geliştirecek. Dijital paradan dijital ekonomiye yeni vahşi düzene geçilirken yoksullar unutulursa yakın bir gelecekte daha ölümcül salgınlar bekliyor bizi. Covid 19'un uyarıları dikkate alınmazsa

Çocuk ve Medeniyet 2021/1 tarihte ilk defa dünya nüfusunun üçte biri çaresiz kalacak.

Bu yeni çaresizlik sarmalının en kırılgan noktası çocuk yoksulluğudur. Tarihte her zaman nüfusun üçte birini oluşturan, buna karşın dünya 
nimetlerinin en azıyla hayatta kalan yoksul çocuk nüfusu farklı salgın hastalıklarla ölüme terk edilecek. Asıl insanlığın çöküş hâli de budur.

Önümüzde bir imkân var: Uzaktan insanlık dönemi'ne karşın yeniden insan merkezli sosyal devleti önermek: Yoksulluk ve çocuk yoksulluğunu kökten çözüme kavuşturacak ve almamız gereken asıl tedbirleri alarak yoksulluğu ortadan kaldıracak politika ve stratejileri geliştirmek ve uygulamak. Bunun için de dünün ekonomik kalkınma (!), büyüme, stratejileri ve "orta gelir tuzağı"yla insanlığı oyalayan anlayış terk edilmeden hiçbir olumlu adım atılamayacağını öğrenmemiz gerekecek... İnsanlık güç ve egemenlik ilişkilerine dayalı kurulu düzenin bütün enstrümanlarına itiraz etmez ve adaleti sağlayacak örgütlenmenin paydaşı olamazsa, Covid 19 sonrası ortaya çıkan imkânı da ıskalamış olacağız. Bu nedenle yoksulluğa karşı toplumlar, ülkeler ve bütün insanlık olarak savunma hattı geliştiremezsek uzaktan insanlık dönemi'nde en ağır bedeli yine yoksullar ve bütün güç koşullardaki insanlar ödeyecek. Bu insanlık durumunu "vicdan" edebiyatıyla, Polyannacılıkla önleyemeyiz. Bu dipsiz kuyudan insanlık ahlakı, merhamet, adalet, paylaşma ve kardeşlikle çıkabiliriz. Yoksulluğun önlenmesine yönelik yeni bir felsefe, bakış açısı, gerçekçi bir dil ve yardım odaklı değil, Hak Temelli, insana ve tabiata saygıya dayalı bir politika gerçekleştiremezsek ülkelerimizi ve dünyayı normalleştiremeyeceğimiz gibi, insanlık gemisi de umut seferine çıkmış olmayacak...

\section{Han Çayırı Yolu Sokağı, 21 Mayıs 2020}

Geçtiğimiz günlerde Türkiye'de koronavirüsün toplumsal etkileri araştırmasının iki sonucu açıklanmıştı: Yoksulluk artacak diyenler yüzde 63.3; Dünyada ekonomik kriz artacak diyenler ise yüzde 76.8 olmuş. Bu iki sonuçtan hareketle şu soruyu sorabiliriz: Ülkelerin ve Dünyanın birinci önceliği yoksulluğun önlenmesi olabilecek mi?. İlk aşamada imkânı olan herkesin ve sosyal destek sağlayabilen gönüllü kuruluşların harekete geçmesi gerekecek. Ülke ve Dünya ölçekli sosyal politikaları hazırlamak için zamana ihtiyaç var. Buna karşılık her ülkede ve yeryüzünün her yaşama ortamında her gün evinin ihtiyaçlarını karşılayarak günlük emeğiyle ailesinin geçimini sağlayan 100 milyonlarca insan için acil desteğin verilmesi gerekiyor.

Salgın sürecinde işsiz kalan ve ekonomik krizle derinleşecek işsizlik ve yoksulluk karşısında her insanın en yakın yoksul komşularına yönelerek iyilik ve kardeşliği yaşamasını da değerli buluyoruz. Hz. Aişe'nin, "Önce komşu sonra ev" çağrısına uyarak çocuk/insan yüzlü devrimler gerçekleştirebiliriz bu uzaktan insanlık dönemi’nde. Hiç de 
küçümsenmeyecek bu çabalarla her insan önce kendinden yola çıkarak iyiliğin ve kardeşliğin öncüsü olabilir.

Çocuk Vakfi, yukarıda vurgulanan amaç doğrultusunda Covid 19 salgını sürecinde imkânı olan her insanı ve aile çevresini yoksul bir komşusuna destek vermek amacıyla ilk çağrıyı yaptı bugün. Karantina günlerine not düşmek amacıyla bu çağrıyı günlüğe not düşüyorum:

\section{ZAMAN ADALET, MERHAMET VE KARDEŞLIK ZAMANI. \\ IMKÂNI OLAN HERKESİ EN YAKININDAKİ YOKSUL AİLE VE ÇOCUKLARA DESTEK VERMEYE DAVET EDIYORUZ.}

Yeni Korona Virüsü salgını kısa sürede bütün insanlığı kuşattı. Ülkemiz ve dünya için daha sıkıntılı günlerin başlangıcı oldu. Ülkemizde nüfusun yüzde 35'i yoksul, yüzde 12'si işsiz. 8,4 milyar Dünya nüfusunun 3 milyarı yoksul, 800 milyonu yoksulluk sınırının altında. Tarih boyunca dünya nüfusunun üçte biri çocuk olduğu halde, hiçbir dönemde dünya nimetlerinden paylarına düşen verilmediği için çocuk yoksulluğu kök saldı. Yoksulların yaşadıklarını ifade edecek hiçbir alfabe yok yeryüzünde...

Bizler evdeyken egemen dünya sistemi yeniden örgütleniyor. Değiş̧im "Yeni Normal" kavramıyla tanımlanıyor. Bu değişimin daha adil bir dünya kurmak için kullanılması gerektiğine inanıyoruz. İnsanlık için savunma hattı oluşturmak ve yoksulların daha derin bir çaresizliğe itilmesini engellemek için; yoksulluk ve çocuk yoksulluğu politikalarının hem dünya hem de ülke genelinde uygulanması gerekir. Bu amaçla; Aile ve Çocuk Bakanlığı'nın kurulmasını ve insan merkezli sosyal devlet taleplerimizi önermeyi ısrarla sürdüreceğiz.

Son aylarda gördük ki; Çin'de hastalanan biri binlerce kilometre ötede bile milyonlarca insanın canını yakıyor. Anladık ki birimizin derdi varken diğerimizin hayatına huzur içinde devam etmesi mümkün değil.

Açlık, yoksulluk ve adaletsizlik en bulaşıcı hastalıktan bile daha tehlikeli. Üstelik bu hastalıkların tedavisini de aşısını da biliyoruz: Paylaşmak. Bütün yoksullar bizim kardeşimiz, bütün çocuklar da bizim çocuklarımız. Bu yüzden herkesi, bu zor günlerde yakınlarındaki yoksul ailelerin ve çocukların yanında olmaya çağırıyoruz. Kendi çocuklarımızla birlikte, ülkemizdeki yoksul çocukların sağlık, beslenme ve eğitimini sağlamak biz yetişkinlerin ve devletin görevi... İstisnasız herkesi, imkanlarının el verdiği ölçüde, bu en büyük insanlık görevini yerine getirmeye çağırıyoruz. Çünkü çocuklar sağlıklı büyüdükçe, geliştikçe ve haklarını yaşadıkça dünyanın daha iyi bir yer olacağına inanıyoruz. 
Zaman adalet, merhamet ve kardeşlik zamanı... Bencillikten uzaklaşarak; dayanışma zamanı. Dünya nimetleri bütün insanlığındır ve biz yoksullara borçlu kaldık. Şimdi ülkemizin ve dünyanın bütün çocukları için ödev ve bu borcu ödeme zamanı...

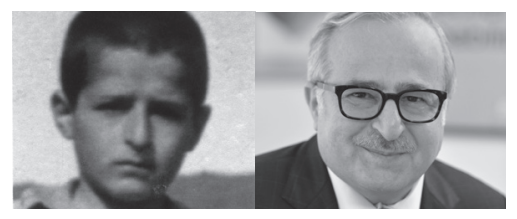

Mustafa Ruhi Sirin 